
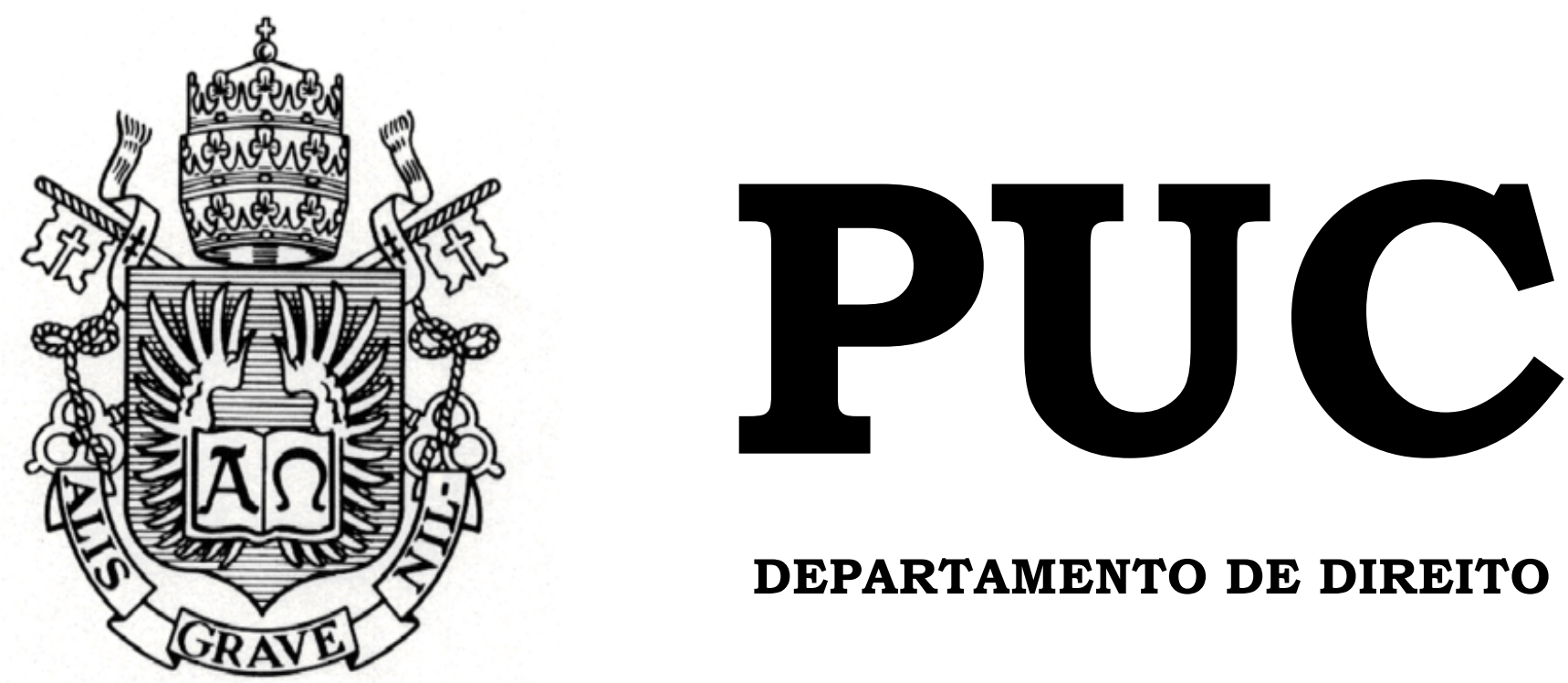

DEPARTAMENTO DE DIREITO

História, Criminologia e Teatro no Tribunal do Júri

por

Antonio Simon Bruno Franchetto Fausto

ORIENTADOR: Sérgio Chastinet Duarte Guimarães

2016.1

PONTIFÍCIA UNIVERSIDADE CATÓLICA DO RIO DE JANEIRO

RUA MARQUÊS DE SÃO VICENTE, 225 - CEP 22453-900

RIO DE JANEIRO - BRASIL 


\title{
História, Criminologia e Teatro no Tribunal do Júri
}

\author{
por \\ Antonio Simon Bruno Franchetto Fausto
}

Monografia apresentada ao Departamento de Direito da Pontifícia Universidade Católica do Rio de Janeiro (PUC-Rio) para a obtenção do Título de Bacharel em Direito.

Orientador: Sérgio Chastinet Duarte Guimarães 


\section{RESUMO}

Inserido dentro de um universo interdisciplinar, o Direito não se restringe unicamente a discussões dogmáticas. Sua complexidade não deve ser avaliada somente com base nas suas normas e abstrações, mas sim dentro de um sistema que, acima de tudo, fornece os elementos necessários à compreensão das instituições de uma determinada sociedade. As arguições em tribunal, as palavras acaloradas em um Júri, os gestos e movimentos de defensores, advogados e acusadores, constitutem um universo específico que se assemelha ao dos rituais, que possuem um script próprio, prédeterminado. $O$ presente trabalho busca entender a relação entre a performance e sua aplicação no Direito, particularmente em sua apresentação mais volúvel, que é o Júri Popular. Trata-se de entender o funcionamento orgânico desse universo, com sua regras próprias, no qual tempo e espaço estão suspensos. Essa cena teatral, porém, não está desvinculada do contexto social mais amplo e das ideologias que sustentam a ordem social e definem a construção criminológica. Por isso, neste trabalho, recorremos também à história do Júri, principalmente no Brasil, a fim de pensar se o modelo do Júri, tido como democrático, é a melhor fonte de justiça que podemos encontrar.

Palavras-Chave: Tribunal do Júri; História; Criminologia; Performance; Teatro; Metodologia. 


\section{SUMÁRIO}

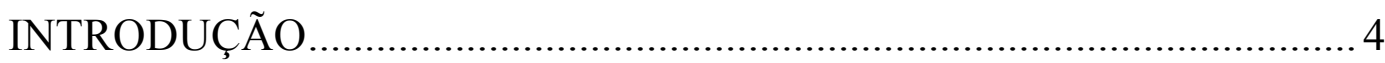

CAPÍTULO 1 - Das Questiones Perpetuae ao Júri no Brasil...................... 10

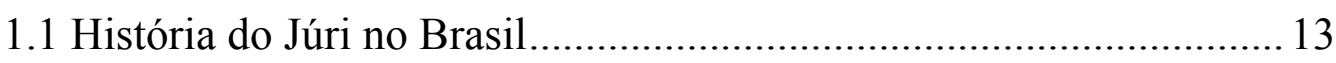

CAPÍTULO 2 - A criminologia no Brasil e a sua influência no Júri........... 19

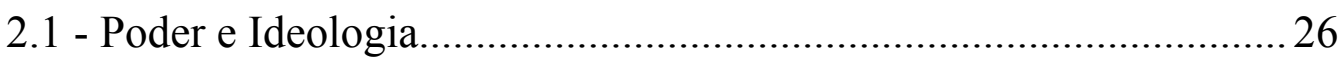

CAPÍTULO 3 - Performance, Teatro e Retórica do Poder ............................ 32

3.1 - A montagem do Palco, linguagem e gestualidade ……………….... 36

3.2 - Regras Procedimentais e a Lei 11.689/08 ……………………....... 42

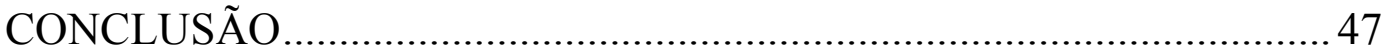

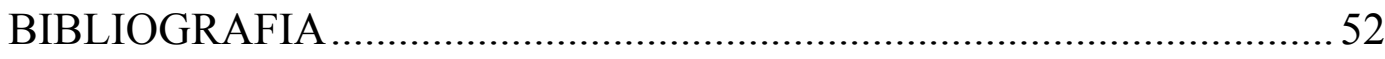




\title{
INTRODUÇÃO
}

O Tribunal do Júri, como instituição, não foi criado somente com objetivo de garantir uma melhor aproximação entre a jurisdição e a justiça social. A exceção criada (já que substitui o poder do juiz), que aparentemente não encontra data certa na própria história ${ }^{1}$, serve de cenário para a perpetuação de valores e costumes sociais. O Tribunal interpreta e ao mesmo tempo cria a base de um ritual, que ilustra o conhecimento acerca do delito e do criminoso. O grande problema desta construção reside justamente nos conceitos e definições ali presentes. Inspiradas em uma antropologia criminal determinista ${ }^{2}$ e em escolas "clássicas" tais como a italiana $^{3}$, estas definições criam os alicerces necessários para punir-se. Como afirma Foucault:

\begin{abstract}
"o laudo psiquiátrico, [...] a antropologia criminal e o discurso da [...] criminologia, introduzindo solenemente as infrações no campo dos objetos suscetíveis de um conhecimento científico, [dão] aos mecanismos da punição legal um poder justificável não mais simplesmente sobre as infrações, mas sobre os indivíduos; não mais sobre o que eles fizeram, mas sobre aquilo que eles são, serão ou possam ser" (Foucault, 1987, p.20).
\end{abstract}

Tendo isto em mente, deve-se firmar parâmetros que permitam avaliar o tipo de comportamento subjacente à construção do Tribunal do Júri. Por isso, ao invés de tentar criticar esse modelo de fora, devemos desconstruí-lo por dentro. E, para tanto, é preciso focalizar o momento

\footnotetext{
${ }^{1}$ A história do júri possui algumas correntes. Vale enfatizar duas delas: a) para os chamados liberais, a criação do júri se deu na Grécia e Roma na época clássica; b) já os conceitualistas ${ }^{2}$ A antropologia criminal visava ao estudo científico e experimental do delito, atribuindo-lhe uma racionalidade classificatória, tal como acontecia com a doença mental, sem, no entanto, tratar dos aspectos sociais, não tomando em consideração a divisão de classes e a exploração.

${ }^{3}$ Uma das principais escolas na época era a positivista italiana. Ela abordava o delinquente através de um caráter plurifatorial. De acordo com essa perspectiva, o indivíduo é compelido a delinquir por causas externas, as quais não consegue controlar, tendo as penas, assim, o objetivo de proteção da sociedade e de reeducação do delinquente. Grandes pensadores daquele tempo, ditos "socialistas", corroboravam essa associação entre crime e inferioridade social. A situação italiana da época marcada pela disparidade entre um sul agrícola e pobre, e um norte potente e organizado proporcionava o ambiente para o desenvolvimento dessa antropologia criminal.
} 
exato em que o Estado está inerte por haver transferido o poder de julgar ao júri popular. Tal objetivo só se alcança "se focarmos na análise do domínio ritualizado em que se expressam, no qual tempo e espaço, já vividos, passam a ser imaginados" (Schritzmeyer, 2012, p.134). As decisões proferidas pelos jurados não demandam uma fundamentação jurídica (formal e racional), sendo baseadas em convicções próprias. Ou seja, não se enquadram em pressupostos legais e não se apresentam nos contextos de origem. Isso altera as regras do jogo do campo jurídico, mas não do campo social. Aqui, os conceitos fazem parte de um ritual próprio, que se supõe refletir um senso comum coletivo; i.e., uma ethos social médio. Tal ethos deve ser alvo da análise do defensor e da promotoria e usado da melhor forma para a arguição no tribunal. Em alguns casos, persuadir os jurados significa levá-los a colocar em questão o sistema de valores e crenças taken for granted. Todas os artifícios legais são legítimos para convencê-los de que, por exemplo, apesar do homícidio, o réu deveria ser privilegiado com o $\S 1^{\mathrm{o}}$ do Art.121 do Código Penal. ${ }^{4}$ Claro, a eficácia depende de um discurso convincente e contundente que faça o júri crer nesta possibilidade. Ao contrário, o Ministério Público deve, na maioria das vezes, garantir a manutenção destes valores, já que neste momento do jogo, não há mais dúvidas quanto a autoria e materialidade do delito ${ }^{5}$. $\mathrm{O}$ combate à criminalidade tal como ela é concebida, deve ser o alvo da promotoria.

Meu foco aqui não é só o resultado, mas também os procedimentos adequados para se chegar a esse resultado. Sugiro, assim, a necessidade de uma boa retórica, imprescindível a qualquer advogado, bem como de certa arte dramática, cuja função é primordial para legitimar aquela cena. As

\footnotetext{
${ }^{4}$ De acordo com este parágrafo, "Se o agente comete o crime impelido por motivo de relevante valor social ou moral, ou sob o domínio de violenta emoção, logo em seguida a injusta provocação da vítima, o juiz pode reduzir a pena de um sexto a um terço".

${ }^{5}$ O juízo de admissibilidade feito pelo juiz da vara criminal, pode acarretar três diferentes decisões: a) a pronúncia, convencido da materialidade do fato e da existência de indícios suficientes de autoria ou participação no crime; b) a impronúncia, quando o juiz não esta convencido da materialidade ou da real participação ou autoria do réu; c) a absolvição sumária, que ocorrerá se provada a inexistência do fato; se provado não ser o acusado o autor ou partícipe do fato; se o fato não constituir infração penal; ou se demonstrada causa de isenção de pena ou de exclusão do crime.
} 
sessões do Tribunal de Júri devem ser tratadas, pois, como um exercício dramatizado do poder ${ }^{6}$. Nas narrativas, tanto dos defensores como dos promotores, o discurso está "embasado em uma certa lógica classificatória e analítica da organização e do funcionamento da vida social" (Schritzmeyer, 2012, p.166). Cada Júri encontrará certa peculiaridade acerca do "elenco", "cenário" e da "trama", que será interpretada, de um lado, pela linguagem verbal e, de outro, pela interpretação silenciosa das aparências, que pressupõem a atribuição de significados a certas variáveis tais como sexo, idade e etnia. A importância do termo "morte" é reconfigurado dentro dessa adjetivação em plenário, que levará em conta os qualificativos inseridos dentro desse contexto ritual, sejam eles identificadores das vítimas ou dos réus. De um ponto de vista não jurídico, o que importa não é a absolvição ou a condenação, e sim fazê-los aderir (personagens e participantes) ao próprio poder em jogo, o qual define as formas legítimas de se punir e de se absolver.

O discurso no júri pauta-se no modelo dialético grego, buscando atribuir ao discurso elementos de razoabilidade e verossimilhança. Não cabe descobrir "uma verdade", mas apenas convencer aqueles que estão aptos a determinar o destino das vidas em jogo. Como bem salientado por Chalita: "...para obter um determinado conhecimento através de um método científico é essencial que haja uma conformidade objetiva com o real. Num julgamento, por outro lado, o que mais importa é que o discurso se conforme às subjetividades envolvidas, à particulariedade do caso e dos acontecimentos" (Chalita, 2007, p.69). Mas a construção da verossimilhança depende do poder da argumentação, cuja função é dar credibilidade aos pontos de vista arrolados. Na retória latina clássica, como nota o próprio Chalita, a argumentatio - também denominada probatio

\footnotetext{
${ }^{6}$ Existe uma relação íntima entre a arte empregada no governo e na cena. A legitimidade do poder de punir se realiza e se confirma por meio do comportamento do advogado e demais personagens, como atores políticos. A aceitação das teses empregadas depende da capacidade de dramatização desse poder e do seu modo de exercê-lo. Assim, "...todo sistema de poder é um dispositivo destinado a produzir efeitos, entre os quais os que se comparam às ilusões criadas pela ilusão do teatro" (Balandier, 1982, p.6).
} 
(Quintiliano) ou confimatio (Cícero) ${ }^{7}$ - opunha-se à teoria da demonstração já que não se fundava na evidência. $O$ raciocínio persuasivo permite chegar à conclusão de que nem toda prova é concebível como redução à evidência. Assim, as provas que constituem esse tipo de discurso podem ser de duas ordens: artificiais e inartificiais. Essa subdivisão feita por Aristóteleles em A Retórica demonstra a importância daquelas provas próprias do discurso, como também àquelas que estão previamente constituídas, desde o testemunho até a jurisprudência dominante. Além disso, na Grécia, a moralidade instrínseca ao discurso do orador perfaz uma boa retórica, já que um advogado não poderia ter sua vida como exemplo de correção, se este não fosse um homem de bem ${ }^{8}$.

A retórica, à arte de falar bem, é antes de mais nada uma técnica de persuasão, envolvendo o uso de diferentes dimensões da linguagem e assim foi ensinada durante séculos na tradição greco-romana. ${ }^{9}$ Porém, a linguagem de per se não joga sozinha. $\mathrm{O}$ ritmo que é dado ao Tribunal do Júri se consubstancia com o bom uso da dicção, entonação e da gestualidade. Além disso, as movimentações de promotores e defensores em plenário, são cruciais para se alcançar um resultado favorável. Outros personagens também constituem esse momento, e serão tratados posteriormente.

A peculiaridade do Tribunal Júri permite a sua comparação com a dinâmica do Ritual e com o Teatro, tal como apresentado no trabalho de Ana Lucia Pastore Schritzmeyer. Um exemplo disso é a importância da

\footnotetext{
${ }^{7}$ Quintiliano era professor de retórica e orador romano. Tratou de reformar a educação fundamental, atribuindo novas características ao modelo de aprendizado. Já Cícero, Questor na Sicíla ocidental em 75 a.C, tornou- se um dos maiores oradores de Roma em uma época marcada por guerras e caos civil. A oratória era uma ferramenta importante para a promoção de si mesmo e de suas ideias, principalmente em eleições, já que não havia meios de comunicações à altura do próprio discurso.

${ }^{8}$ A noção de homem de bem é um conceito antigo, que pode ser esclarecido por essa citação de Quintiliano: "O que melhor caracteriza a retórica, é ter sido definida como a ciência do dizer bem, porque isto abrange ao mesmo tempo todas as perfeições do discurso e a própria moralidade do orador, visto que não se pode verdadeiramente falar bem sem ser um homem de bem" (Quintiliano, 1865, p.180 apud Chalita, 2007, p.77-78)

${ }^{9}$ Ela só viria a perder seu prestígio com a emergência de um novo discurso científico, da razão analítica, principalmente com a lógica estabelecida pelo modelo cartesiano. Em $O$ Discurso do Método, Descartes reputa como falso tudo aquilo que é apenas verossímel, atribuindo ao exercício da retórica concepções genéricas e homogêneas.
} 
separação de papéis instrínseca ao processo de ritualização. Como afirma Roberto DaMatta:

"(...) os rituais fundados no reforço (ou na separação) são rituais que guardam uma relação direta com as rotinas do mundo quotidiano. Assim, por exemplo, "um general é sempre um general; apenas acontece que, num determinado momento estabelecido pelo grupo, ele usa as vestes, condecorações e armas correspondentes ao seu posto de identidade. Reforça-se o posto que existe e que pode estar, em virtude de outras rotinas e sistema de posições, submerso. O chamado ritual de separação é justamente esse momento onde é destacado o papel de general e são inibidos todos os outros" (DaMatta, 1983, p.61 apud Schritzmeyer, 2012, p.153).

Basta mudarmos o general por personagens do Júri (defensores, promotores, juiz...) e veremos como os papéis de cada um são reforçados e reconfigurados, o que não se evidencia quando os mesmos ainda se encontram nos corredores do Fórum, quando os ternos e as gravatas passam na maioria das vezes despercebidos. Outro ponto a ser salientado são os efeitos reflexos provocados pelos julgamentos nos tribunais de júri. O ritual se apresenta como um dromenon ${ }^{10}$, ou seja "...ele é realmente reproduzido na ação" (Huizinga, 1980, p.18). Não existe portanto uma demonstração figurativa, imitativa de per se. Trata-se de uma ação que toma forma de espetáculo, que é delineado pela representação do acontecimento. Além disso, através do julgamento é possível destacar normas morais e ideias de relações sociais, evidenciando assim ao mesmo tempo a "realidade fragmentada e conflituosa da aplicação cotidiana das normas" (Shritzmeyer, 2012, p.163).

Já o lugar da dramaturgia nesse espaço deve ser analisado a partir de duas premissas: uma objetiva e outra subjetiva. Quanto à primeira, é necessário entender a encenação no Tribunal do Júri como uma arte teatral que joga com as noções de uma sociedade, em particular aquelas acerca de

\footnotetext{
10 "Palavra grega para ritual, dromenon é uma coisa feita, uma ação. Desta maneira, os gregos entendem que para realizar um ritual é preciso fazer algo, ou seja, reagir ao impulso dado. Johan Huizinga reflete, no livro 'Homo Ludens', que a matéria desta ação é um drama, isto é, um ato, uma ação representada num palco. As duas palavras gregas, dromenon ( $\delta \rho \omega ́ \mu \varepsilon v o v)$ e drama

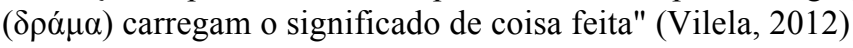


um paradigma punitivista. Portanto, deve estar ao alcance de qualquer defensor ou promotor, a capacidade de analisar elementos culturais, econômicos e sociais para a construção de uma boa tese que consiga alimentar esse sistema ou que possibilite sua revogação legítima. A outra premissa, esta de caráter subjetivo, consiste na sedução dos jurados a partir de técnicas específicas. A eficácia do discurso depende de uma sintonia entre emissor e receptor da mensagem, que ultrapassa os significados literais transmitidos pelas palavras. Encontramos aqui a função essencial das emoções e da gestualidade. Como sugere Stanislavski ${ }^{11}$ acerca da construção do personagem: "Em cena, não corram por correr, nem sofram por sofrer. Não atuem de modo vago, pela ação simplesmente, atuem sempre com um objetivo" (Stanislawski, 1984, p.69).

O teatro proporciona um momento único, a qual toda ação representa e tem um significado específico. Os roteiros definem um caminho a ser seguido pelos personagens, que na maior parte das vezes não deixa margens para interpretação. Não quero dizer que o teatro não proporciona uma série de reflexões a cerca do tema interpretado. Mas o resultado já se encontra presente no tempo, já se define em quanto tempo todas aquelas ações terão desfecho. No júri porém, as representações são subjetivas. Esclareço. Tanto do ponto de vista de quem atua como de quem assiste, as histórias serão interpretadas de forma diferente. No júri ou no teatro, estar em cena é poder jogar o jogo, e este jogo tem regras constitutivas, isto é, regras que instauram a própria possibilidade do jogo. Mas a condenação ou a absolvição, dependem de outro fator: não apenas conhecer as regras do jogo, mas, além disso, saber atuar, saber usá-las com destreza. Trata-se, pois, de entender o mundo do júri de dentro para fora, de sua prática para suas regras e sua relação com a sociedade.

\footnotetext{
${ }^{11}$ Constantin Stanislavski foi um escritor, ator e diretor russo, tendo sido um dos mais influentes pensadores do teatro entre o final do século XIX e início do XX. Seu método de preparação de atores e construção de personagens representou uma revolução na dramaturgia e, hoje, suas técnicas são utilizadas na maioria das escolas de teatro pelo mundo.
} 


\section{CAPÍTULO 1 - Das Questiones Perpetuae ao Júri no Brasil}

Embora, como vimos, muitos autores não consigam definir o momento e o local exato em que foi criada a instituição do Júri, é inegável a contribuição do Processo Penal Romano Acusatório tanto nos dispostivos concernentes ao Júri como de um modo geral ao próprio sistema processual penal. Essa contribuição também é constatada quando fugimos do objeto de estudo histórico e passamos a focalizar os critérios adotados quanto à política criminal em sede legislativa, como também quanto ao próprio sistema de valoração em sede positiva.

Durante o segundo período evolutivo do processo penal romano, conhecido como Indigitado Acusatório $^{12}$, foi criado como orgão jurisdicional a chamadas Questiones Perpetuae. O instituto que substituiu as assembléias populares se deu justamente no período de maior republicanismo por parte do Estado romano, advindo da necessidade de se investigar mais eficientemente certos crimes, mais notadamente a concussão praticada por magistrado provincial. Tratava-se claramente de uma tentativa de manter-se a legalidade de forma imparcial, já que o julgamento não poderia ser submetido a quem praticava a jurisdição privada (Pretor) ou mesmo à coercitio do Cônsul ou do próprio Pretor. As questiones substituíram em um primeiro momento os colégios de juízes que eram designados para julgar os casos de concussão por magistrado, porém dado a frequência com que os fatos eram cometidos, as questiones passaram a ser também perpétuas. O caráter mais técnico e autônomo dos julgamentos se dava justamente na seara penal, já que existia muita pressão e influência política no processo como um todo. Ademais, o próprio

\footnotetext{
${ }^{12}$ Trata-se de um período que intercala dois momentos processuais de caráter essencialmente inquisitivo. Na primeira fase processual, também denominada cognominado comicial, as matizes inquisitivas eram preponderantes, sendo que o trabalho investigativo era feito de ofício pelos próprios agentes estatais e, posteriormente, por parte dos próprios cidadãos romanos. A terceira fase processual, cognitio extra ordinem, que constitui a volta da inquisitividade no processo penal, é constituído de orgãos jurisdicionais ligados diretamente ao príncipe, que também atuava por vontade própria.
} 
procedimento adotado nas questiones tinha fundamento legal, já que previamente foi estabelecida uma lei que regia todos os crimes e as respectivas penas a serem impostas. Outro ponto interessante é o fato dos jurados serem escolhidos pelo Pretor, estando ausente portanto qualquer interferência das partes. Além disso, alguns dispositivos se comparam aos requisitos instituídos pela legislação ordinária penal brasileira, já que também os jurados deveriam responder pela sua idoneidade a fim de fazerem parte do júri. Inicialmente, somente Senadores poderiam fazer parte do corpo de jurados, o que gradativamente foi mudando (incluindo os cavaleiros e os tribunos do Erário), porém sem alterar os requísitos objetivos para se tornar um "julgador".

A imputação era feita por qualquer cidadão romano, que assumia todos os direitos e deveres inerente à qualidade de parte em sentido processual. A partir desse momento, a ação penal tornava-se de caráter, , indisponível, assim como acontece nos dias atuais após oferecida a denúncia por parte do Ministério Público ${ }^{13}$. O autor portanto, não atuava em nome da vítima e sim da coletividade. A figura de um acusador popular era de extrema importância para o próprio cidadão que possuía, por exemplo, certas pretensões políticas ou mesmo a assunção de um cargo público, que era porventura ocupado pelo acusado condenado. Adquirida a condição de acusado, o mesmo passava a ter seu nome em uma tábua (esse in reatu), uma espécie de ficha criminal, que gerava uma série de gravames temporários tanto na seara penal como civil, passando a ter parte dos seus bens indisponíveis (Malan \& Saad, 2005, p.6).

$\mathrm{O}$ acusado respondia por via de regra em liberdade, tendo como última ratio o pedido de prisão. No direito pátrio atual, a prisão antes de transitada em julgado a sentença ${ }^{14}$ deve ser a última ratio do julgador,

\footnotetext{
${ }^{13}$ Segundo o art.42 do Código de Processo Penal do Brasil: "O Ministério Público não poderá desistir da ação penal".

${ }^{14}$ Em um julgamento recente de um Habeas Corpus (HC 126292), o Ministro do Supremo Tribunal Federal, Teoria Zavascki, relator do caso, ressaltou em seu voto uma mudança de pensamento, passando a entender que a execução provisória de acórdão penal condenatório proferido em grau de apelação, ainda que sujeito a recurso especial ou extraordinário, não fere o
} 
devendo ser requerida pelo Ministério Público somente em casos graves, nos quais caberia um pedido de prisão preventiva ou mesmo uma prisão temporária. Quanto à absolvição ou condenação, o resultado final dar-se-ia por maioria dos votos, porém no caso de empate a decisão era favorável ao acusado, em nome do princípio do favor rei, já que haveria, ainda, alguma dúvida para se condenar.

Com o fim da República e início do Império Romano, as instituições sofreram uma séria de mudanças. A competência das questiones que havia se ampliado e muito na segunda fase, teve mais uma vez sua abrangência reduzida. Por exemplo, nos crimes de concussão que passaram a ser da jurisdição do próprio Senado, o qual juntamente com o Imperador ficaram responsáveis por designar os acusadores. Estava instaurada a fase essencialmente inquisitiva do processo penal romano, com uma série de medidas que suprimiram qualquer tipo de ampla defesa e contraditório, além de diversos outros príncipios inerantes ao processo penal de caráter acusatório puro.

As questiones formaram um embrião daquilo que é tido atualmente como Tribunal do Júri no Brasil. Procedimentos similares àquele então adotados podem ser listados da seguinte forma, como preceitua Diogo Malan em sua tese, "Origens Históricas dos Sistemas Acusatório e Inquisitivo":

\footnotetext{
"(i) forma de recrutamento dos jurados: cidadãos de notória idoneidade, cujos nomes constam de lista anualmente confeccionada pelo juiz-presidente (Código de Processo Penal), arts. 436, 439, 440 e 441); (ii) denominação dos componentes do orgão juridicamente popular: jurados (CPP, art. 433); (iii) formação do órgão judicante mediante sorteio (CPP, arts. 427, 428 e 429); (iv) recusa de certo número de sorteados, sem necessidade de motivação (CPP, art.459, § 2.); (v) prestação de juramento por parte dos jurados (CPP, art. 464); (vi) metodologia de votação, mediante respostas simples e objetivas: sim ou não (CPP, art. 485): (vii) decisão tomada por maoiria de votos (CPP, art. 488); (viii) soberania dos veredictos (CR/88, art.5, XXXVIII); (ix) atribuição do juiz-presidente (CPP, art 497); (x) indispensabilidade de comparecimento do acusado para realização do julgamento (CPP, art.449)" (Malan \& Saad, 2005, p.10)
}

príncipio constitucional da presunção de inocência, mudando toda a ratio do constituinte originário que prevaleceu desde a Constituição de 1988. 
Vejamos, agora, um breve apanhado da história do júri no Brasil.

\subsection{História do Júri no Brasil}

A história do Júri no Brasil tem estreita relação com as profundas mudanças de cunho liberal ocorridas em Portugal na primeira metade do século XIX. A Revolução Liberal do Porto, eclodida em 24 de agosto de 1820, cujo objetivo era a criação de uma Assembléia Constituinte, foi fundamental para que houvesse a constitucionalização de um tribunal formado por jurados livres e independentes da monarquia. Assim, a Carta Constitucional portuguesa de 1821 determinava no Art. 177 que: "Haverá Juízes de Facto assim nas causas crimes como nas cíveis, nos casos e pelo modo que os Códigos determinarem". Além disso, foi regulamentada a liberdade de imprensa, criando-se um conselho de juízes de fato para julgar delitos cometidos por abuso à liberdade de imprensa. Ampliou também em seu Art. 57, a possibilidade de entrar com recurso caso haja nulidade ou inaplicação da pena correspondente ao delito cometido.

Em consonância com essas mudanças, o então Príncipe Regente D. Pedro I estabeleceu através do decreto de 18 de junho de 1822, a primeira aparição de um Tribunal do Júri em território brasileiro ${ }^{15}$. Cabe salientar, que não se trata do primeiro Tribunal de Júri no ordenamento brasileiro, já que a independência do Brasil só viria mais tarde neste mesmo ano.

A competência do tribunal era exclusivamente quanto a crimes contra a imprensa, fato que demonstra a necessidade da Coroa portuguesa em controlar a sua atuação, de modo a evitar qualquer tipo de insubordinação ao sistema unitário da monarquia. O tribunal era composto por 24 "juízes de facto", nomeados pelo corregedor e pelos ouvidores do

\footnotetext{
${ }^{15}$ De acordo com Frederico Marques: "Coube ao Senado da Câmara do Rio de Janeiro, em vereação extraordinária de 4 de fevereiro de 1822, dirigir-se a Sua Alteza, o Príncipe Regente D. Pedro, solicitando a criação do Juízo dos Jurados , para execução da Lei de Liberdade de Imprensa no Rio de Janeiro, 'aonde a criação do Juízo dos Jurados parece exeqüível sem conveniente, atenta a muita população de que se compõe, e as muitas luzes que já possui'.” (Marques, 1963, p.15)
} 
crime, a partir de um requerimento do procurador da Coroa e da Fazenda (Marques, 1963, p.15). Constituía prerrogativa do réu a recusa e por consequência a eliminação de até 16 desses juízes. A soberania das decisões do júri, como ainda não emancipado politicamente, era relativa, determinando-se que qualquer recurso da parte ré, fosse julgado pelo atual Príncipe Regente. Além disso, o júri era composto por homens com alta renda e posses, o que tornava questionável o caráter julgador do instituto.

A independência do Brasil mudou o ordenamento jurídico até então vigente. As estruturas do Júri, principalmente com o advento da Carta Maior em 1824, sofreram mudanças significativas. A principal delas é a integração do tribunal como órgão do Poder Judiciário. Além disso, a forte influência inglesa, quanto à divisão em Júri de Acusação e Júri de Sentença, determinou uma nova organização espacial e de julgamento ${ }^{16}$. Outro ponto a se salientar é o fato da competência ter-se ampliado para outras searas do direito, como por exemplo a área cível. Em 29 de novembro de 1832, surge o Código de Processo Penal do Império, ampliando ainda mais a competência do tribunal ${ }^{17}$, extinguindo praticamente todas as formas de jurisdição ordinária. Ademais, consagrou o número de 60 jurados sorteados, dos quais 23 formariam o Júri de Acusação e 12 o Júri de Sentença. Poderia compor este corpo todos os cidadãos de bem, excluindo qualquer autoridade, tais como senadores e deputados. Deste total, acusadores e defensores podiam por recusa imotivada excluir até 12 desses jurados no Júri de Sentença. O julgamento do mérito, portanto, era diretamente

\footnotetext{
16 "No dia de Júri de acusação, eram sorteados sessenta juízes de fato. O juiz de paz do distrito da sede apresentava os processos de todos os distritos do têrmo, remetidos pelos demais juízes de paz, e, preenchidos certas formalidades legais, o juiz de direito, dirigindo a sessão, encaminhava os jurados, com os autos, para a sala secreta, onde procediam a confirmação ou revogação das pronúncias ou impronúncias. Constituíam, assim, os jurados, o conselho de acusação. Só depois de sua decisão, podiam os réus ser acusados perante o conselho de sentença. Formavam êste segundo Júri doze jurados tirados à sorte: à medida que o nome do sorteado fôsse sendo lido pelo Juiz de direito, podiam o acusador e o acusado ou acusados fazer recusações imotivadas, em número de doze, fora os impedidos.” (Marques, 1963, p.17)

17 "Imitando as leis inglesas, norte-americanas e francesas, deu-se ao Júri atribuições amplíssimas, superiores ao grau de desenvolvimento da nação, que se constituía, esquecendo-se, assim, o Legislador de que as instituições judiciárias, segundo observa MITTMAIER, para que tenham bom êxito, também exigem cultura, terreno e clima apropriados." (Filho, Candido de Oliveira, 1932, p.9-10 apud Pinto, 2005, p.9.)
} 
veiculado à confirmação ou revogação das pronúncias e impronúncia no Júri de Acusação. Das decisões emanadas pelo Júri, a pena de morte só se daria por unanimidade do Conselho de Sentença. Caso isso não acontecesse, uma pena menor seria imposta mesmo que alcançado os $2 / 3$ necessários. A partir desse veredicto o único recurso cabível era a apelação ao Tribunal da Relação, no prazo de até oito dias. As possibilidades giravam em torno da realização de um novo júri, principalmente se não fosse assegurada as formas essenciais do processo ou mesmo se o próprio juiz singular não se sentira conformado com a decisão dos jurados.

Após esse período foram feitas algumas mudanças a fim de restringir certas competências e individualizar ainda mais o processo de escolha dos jurados. Um exemplo disso é o Regulamento $\mathrm{n}^{\circ} 120$ de 1842, que trouxe certos requisitos como renda mínima e grau de cultura para ser legítima a participação. O Art. 225 dispunha desta forma:

\footnotetext{
Art.225. São aptos para ser jurados os cidadãos:

$1^{\circ}$ Que puderem ser eleitores.

$2^{\circ}$ Que souberem ler e escrever.

$3^{\text {o }}$ Que tiverem rendimento annual, por bens de raiz, ou Emprego Público quatrocentos mil réis nos Termos das Cidades do Rio de Janeiro, Bahia, Recife, S.Luiz do Maranhão; trezentos mil réis nos Termos das outras Cidades, e duzentos mil réis em todos os demais Termos. Quando o rendimento provier de commercio, ou industria, deverão ter o duplo.
}

Além disso, desde 1835 não havia possibilidade recursal para escravos, inclusive quanto à pena de morte, o que demonstra o recrudescimento deste novo regime. O Júri de Acusação fora substituído por juízes municipais e autoridades policiais, que agora tinham a competência para fomar a sentença de pronúncia. A pena de morte que até então era sentença tida por unanimidade, passava ser de apenas $2 / 3$ do Conselho e para as demais somente era necessário obter a maioria dos jurados. O Júri Popular também perdeu a competência quanto a crimes cometidos na esfera cível.

Com o passar do tempo e já perto do final do Império, algumas mudanças foram efetuadas de modo a melhorar o devido processo legal. 
Alguns dispositivos promulgados durante a década de 1840 foram revogados, como a votação não unânime no caso de pena de morte (voltando a ser unânime em todos os requisitos como qualificadoras e agravantes) e a necessidade de $2 / 3$ para as demais penas a serem impostas. Ainda na esteira dessas transformações, já que o Júri de Sentença apresentava 12 jurados, no caso de empate deveria ser aplicado o princípio do favor rei, sendo o réu portanto absolvido com relação à aplicação da pena determinada.

A proclamação República em 15 de novembro de 1890 consagrou por meio do Decreto $n^{0} 4.992$ de 3 de janeiro de 1891 uma nova figura até então inoperante no Brasil: O Júri Federal. Este era responsável pelo julgamento de crimes como peculato, falsidade, violação de sigilo de correspondência, estelionato entre outros crimes da justiça federal comum ${ }^{18}$. A Constituição de 1891 passou o Tribunal do Júri ao rol das garantias individuais (fato este que mudaria com a Constuição de 1934, na qual o Júri inserir-se-á novamente na parte dipositiva referente à estrutura do Poder Judiciário). As dúvidas, porém, subsistiam, de modo que não se sabia exatamente quais seriam as características atribuídas à continuidade do Instituto, agora sob novo regime. A jurisprudência do STF em acórdão de 7 de outubro de 1899, tratou de eliminar essas dúvidas:

São características do Tribunal do Júri: (...) II - quanto ao funcionamento:

a) a incomunicabilidade dos jurados com pessoas estranhas ao Conselho, para evitar sugestões alheias,

b) alegações e provas da acusação e defesa produzidas publicamente perante ele,

c) atribuição de julgarem estes jurados segundo sua consciência

d) irresponsabilidade do voto emitido contra ou a favor do réu. (Marques, 1963, p.22-23)

Além disso, a doutrina resolveu traçar ainda algumas características essenciais que não poderiam ser alteradas pelo legislador, tais como: o

\footnotetext{
${ }^{18}$ Estas competências do Tribunal viriam a ser suprimidas em 27 de dezembro de 1923 através do Decreto no 4780 e, posteriormente, o próprio Júri Federal viria a ser extinto.
} 
número ímpar do Conselho Julgador, a soberania das decisões, a atribuição privativa para julgamento de crimes contra a vida e a ampla defesa.

As mudanças foram paulatinas com o advento das demais Cartas Constituicionais ao longo do século XX. A outorga da Constuição de 1937, por exemplo, nada dispôs sobre o Instituto em questão, ganhando mero status de Lei Ordinária, a qual poderia ser revogada a qualquer tempo. Quem veio a regulamentar o Instituto do Júri Popular, foi o Decreto Lei ${ }^{\circ}$ 167 de 1938, que apresentou nova interpretação quanto a Soberania dos Veredictos, já que caberia no caso de "injustiça da decisão", recurso ao Tribunal de Apelação. A nova decisão, muitas das vezes, levava a reforma in pejus de veredictos absolutórios, condenando a penas muito elevados. Somente com a Constituinte de 1946, o Júri voltou a ter status de um Tribunal impelido pelo "mais puros e sinceros ideiais democráticos" (Marques, 1963, p.26).

A grande mudança viria apenas com a Constituição de 1988. O Instituto foi mais uma vez elencado no rol de garantias fundamentais recebendo o status de cláusula pétrea, não podendo ser destituido por nenhum constituinte derivado. Como proclama o referido dispositivo:

Art. $5^{\circ}$ XXXVIII - é reconhecida a instituição do júri, com a organização que lhe der a lei, assegurados:
a) a plenitude de defesa;
b) o sigilo das votações;
c) a soberania dos veredictos;
d) a competência para o julgamento dos crimes dolosos contra a vida;

Deste modo, a garantia da plenitude de defesa é inserida no Princípio corolário, a mais ampla aplicação do direito em toda história do Instituto. Podemos citar como exemplo dessa garantia, a necessidade de heterogeneidade na composição do júri, de modo que as ideologias inerentes aos diversos estratos sociais não fossem primordiais para se distorcer a justiça do julgamento. Além disso, houve uma mudança substancial no Código de Processo Penal (CPP) em seu Art. 366, promovido pela Lei 9.271/96. A diferença tange justamente ao caso da 
ausência do réu em qualquer ato do processo, que anteriormente passava a se tornar rével após citado inicialmente ou intimado. Com a nova Lei, o processo e o prazo prescricional passaram a ser suspensos, não sendo mais julgado à revelia. A jurisprudência tratou de delinear os parâmetros para a aplicação do referido dispositivo:

\begin{abstract}
"No procedimento dos crimes dolosos contra a vida existem duas fases distintas, sendo certo que nos casos de crimes inaficançáveis, como o destes autos, somente é possível o inicio da segunda fase com a presença do réu, eis que a Lei exige intimação pessoal dos termos da pronúncia (art. 414, CPP) e também se faz necessária a presença do réu em Plenária de júri (art. $451, \S 1^{\circ} \mathrm{CPP}$ ) onde serão produzidas as provas a serem analisadas pelos jurados quando das respostas aos quesitos". ${ }^{19}$
\end{abstract}

Outro ponto a ser sublinhado é a soberania das decisões do Júri. O conceito de soberania dos vereditos ultrapassa o sentido literal e significa "a impossibilidade de os juízes togados se substituírem aos jurados, na decisão da causa. Júri soberano, portanto, é aquele ao qual não se substitui nenhum magistrado para julgar uma questão criminal já decidida pelos jurados" (Marques, 1963, p.38). Com as mudanças promovidas pelo CPP de 1941, além da possibilidade de realização de um novo júri caso a decisão tenha sido manifestamente contrária as provas dos autos, ficou a cargo do próprio Tribunal o novo julgamento, não sendo de competência de Tribunal Superior ou de qualquer outra instância ${ }^{20}$. Cabe ressaltar por fim, a organização do Tibunal que passou a ser formado por um juiz togado e 25 jurados sendo 7 escolhidos e responsáveis para compor o Conselho de Sentença. Todo o procedimento e organização estão presentes entre os arts. 406 e 497 do Código de Processo Penal, responsável pela definição do processo de crimes julgados pelo Júri Popular.

\footnotetext{
${ }^{19}$ TJ/RJ; 8 Câmara Criminal; HC 2004.059.06764; Des. Rel Flávio Magalhães; julg. 27.01.2005

20 "Em respeito ao princípio constitucional da soberania dos veredictos do Tribunal do Júri, expresso no art. $5^{\circ}, \mathrm{XXXVII}$, "c", da Carta Magna, o legislador infraconstitucional restringiu a possibilidade de interposição de recursos contra as sentenças condenatórias originadas daquele órgão julgador. O Código de Processo Penal, diante do exposto, só admite que se recorra de decisão condenatória proferida pelo Conselho de Sentença nas hipóteses taxativamente elencadas nos arts. 593, III (apelação) e 607 (protesto por novo júri), que, conseqüentemente, hão de ser aplicados da forma mais restritiva possível." (TJ/RJ; $7^{\text {a }}$ Câmara Criminal; Ap. Criminal 2005.050.01733; Des. Rel Eduardo Mayr; julg. 28.06.2005)
} 


\section{CAPÍTULO 2 - A criminologia no Brasil e a sua influência no Júri}

Apresentada uma breve história do Júri no Brasil, fazem-se necessárias agora algumas explicações acerca da influência do pensamento criminológico positivista no Direito Penal brasileiro e também do processo de criminalização daqueles atos considerados marginais em relação às normas sociais.

A grande crítica ao Júri reside justamente na falta de experiência na arte de julgar e também da atecnia do jurado em comparação à de um magistrado. Por outro lado, apesar da independência face ao poder público - que aliás foi importantíssima no período histórico em que se deu a transição do absolutismo para o estado de direito levando à abolição da teoria e do uso medieval das provas - o Júri permite a construção de uma modelo de julgamento influenciado pelo costumes e estereótipos de uma determinada sociedade, a qual, em nosso caso, é fortemente marcada pela exclusão e pelo "pré(conceito)". A constituição desse pensamento deve-se, de um lado, às diferentes teorias criminológicas, em especial a de Lombroso $^{21}$ e, de outro, aos contextos históricos o qual o Brasil se inseriu desde então.

Imaginava-se que, em um lapso de tempo relativamente curto, o Brasil conseguiria passar de uma Monarquia que representava valores arcaicos e instituições anacrônicas, a uma sociedade em busca de civilidade e progresso, tentando adaptar a vida pública e privada aos ensinamentos dos países modelos desse tipo de desenvolvimento, em especial aqueles da Europa ocidental (Ferreira, 2010, p.51). Contudo, embora tenha mudado de regime político, a nascente democracia brasileira era muito limitada: de um lado, pelo número pequeno de eleitores, já que ainda se observava a

\footnotetext{
${ }^{21}$ A aceitação das ideias de Lombroso no Brasil se dá em um momento de efervescência cultural e científica, marcada pela influência positivista, além da turbulência social, econômica e política das primeiras décadas do século XX.
} 
necessidade de ser alfabetizado para exercer o direito e também pelo fato do voto ser aberto, o que causava uma série de abusos e coações por parte dos políticos, a fim de obter os votos necessários para serem eleitos. O Brasil rural mantinha fortes relações sociais de subserviência e concentração de poder local, dando lugar ao fenômeno do coronelismo, classicamente estudado pelo Dr. Victor Nunes Leal em Coronelismo: Enxada e Voto.

Embora a estrutura agrária, sobretudo no nordeste brasileiro, tenha se mantido quase inalterada ao longo da Primeira República, o desenvolvimento da economia cafeeira no sudeste e as grandes ondas migratórias - que se iniciaram ainda na segunda metade do século XIX e perduraram nas primeiras décadas do século XX - vieram a alterar profundamente a composição social brasileira. $\mathrm{O}$ desenvolvimento industrial possibilitado pelos excedentes da exportação cafeeira e uma crescente urbanização, levou a uma diversificação crescente da sociedade brasileira e um alargamento progressivo do contingente de eleitores admitidos pelas leis eleitorais. Se na eleição de Prudente de Moraes em 1894 votaram apenas 2\% da população brasileira, que representava 329.174 mil votos, naquela que encerraria a Primeira República, em 1930, foram cerca de $6 \%$ a 7\%, totalizando 1.834 .523 milhões de votos ${ }^{22}$.

Será apenas na Era Vargas, contudo, que a legislação eleitoral será efetivamente mudada, com a instauração do voto secreto e obrigatório, além da instauração do voto feminino. Apesar desse avanço em direção a uma democracia mais ampla, a Era Vargas foi marcado por uma série de atitudes centralizadoras. Com a instauração do chamado Estado Novo, assistiremos à extinção de orgãos legislativos federais, estaduais e municipais, além da suspensão dos direitos constitucionais. Em 1937 o Estado de Sítio é declarado:

"Em 1937, por um ato de força, o Presidente Getúlio Vargas, com apoio do General Góis Monteiro, este Ministro da Guerra, e de outras patentes militares que com o Ministro tinham se reunido a 27 de setembro de 1937, resolveu romper com a ordem constitucional, sob fundamento de que, assim procedendo, se poria fim à ameaça comunista, que mesmo

\footnotetext{
${ }^{22} \mathrm{O}$ total de votos foi retirado do site http://pt.wikipedia.org/
} 
após a chamada Intentona Comunista, de 1935, ainda se fazia presente (Pierangeli, 2001 apud Ferreira, 2010, p.55)".

Porém, o governo possúia grande apoio popular já que promulgou uma série de direitos trabalhistas, como também aumentou o salário mínimo vigente na época. Assim, "...o turbulento período enfrentado pelo Brasil entre 1900 e 1940, fortaleceu a política da segurança nacional, que visava, da mesma forma que a Escola Positiva, o aprimoramento dos instrumentos de Defesa Social. Conforme referido anteriormente, as similaridades entre o Brasil e a Itália, não se limitaram a crise econômica, social e política enfrentada, pois em ambos os países, o resultado do conturbado período foram ditaduras de extrema direita, com Benito Mussolini governando o estado italiano e Getúlio Vargas liderando o estado brasileiro" (Ferreira, 2010, pg.55). ${ }^{23}$

Ambas as nações, tanto a Itália como o Brasil, tiveram grande influência do pensamento Lombrosiano e da Escola Positivista no processo de criação da sua legislação penal e da produção doutrinária e criminológica. Lombroso criara diversas hipóteses para definir quem seria L'Uomo Delinquente, título de sua principal obra, publicada em Milão em 1876. As idéias iniciais de Lombroso, tais como a da criminialidade nata, a possível semelhança do criminoso com o louco e a constatação de certas anomalias fisicas, deixaram de ser seu principal enfoque, já que passou a estabelecer o atavismo (hereditário) como principal causa da delinquência. Uma série de estudos físicos e fisiológicos foram feitos a fim de que fossem constatados certas atribuições características de ascendentes distantes, determinando assim as anomalias presentes no indivíduo, as quais Lombroso denominava estigmas. Porém, suas constatações foram rasas, sem dados que comprovassem uma série de alegações. Cabe salientar, que um dos casos mais famosos do final do século XIX, demonstram a clara aplicação dos postulados lombrosianos a seara penal brasileira. Com o fim

\footnotetext{
${ }^{23}$ É bem verdade, que o populismo de Getúlio Vargas acabaria reclamado por linhagens da esquerda trabalhista no Brasil, mas o regime do Estado Novo que dura de 1937 até o final da II Guerra Mundial é, claramente, autoritário e ditatorial.
} 
da Guerra de Canudos em 1897, foi solicitada a cabeça de Antonio Conselheiro, para que a partir de uma análise pormenorizada fosse constatado o atavismo. Apesar disso, nenhum elemento comprobatório de ordem científica foi capaz de apresentar nenhum indício da hipótese em questão ${ }^{24}$.

Além disso, uma série de outros elementos indiciais passaram a ser adotados na identificação de criminosos. Assim, por exemplo o uso de jargãos, que dificultava a compreensão daqueles que não faziam parte do mundo da criminalidade, seria visto como marca de um sentimento nato doentio, cheio de orgulho e vaidade. A deliquência era tida como um orgulho para aqueles que cometiam crime, sendo suas ações plenamente justificáveis para si mesmos. Outro aspectos como o jogo, o alcool e a preguiça perfaziam a imagem perfeita daquela pessoa desprovida de bons padrões morais e mais aptas a cometer crimes.

A situação carcerária era, para Lombroso, uma demonstração de que não era possível ressocializar criminosos. Os índices de reincidência eram enormes, o que demonstraria a incapacidade do insituto de lidar com o problema. Assim, a única solução seria a pena de morte ou a prisão perpétua, mesmo que sua teoria de "hereditariedade criminal" justificasse o surgimento do "criminoso", diversos outros fatores poderiam influenciar nas tendências deliquentes. Portanto, para além das legislações penais, a idéia de crimininalidade nata, conduziria a necessidade de criação de códigos de segurança nacional, garantindo o afastamento destes infratores do convívio social. Cabe salientar, que o discurso da Doutrina de Segurança Nacional atuou em contextos posteriores, principalmente naquelas ditaduras do conesul na década de 60 e 70. Porém, mantém íntima relação com o discurso científico da Escola de Criminologia Positivista do final do século XIX.

\footnotetext{
${ }^{24}$ Nas palavras de Euclides da Cunha a respeito de Antonio Conselheiro: "Evitada a intrusão dispensável de um médico, um antropologista encontrá-lo-ia normal, marcando logicamente certo nível da mentalidade humana, recuando no tempo, fixando uma fase remota da evolução. $\mathrm{O}$ que o primeiro caracterizaria como caso franco de delírio sistematizado, na fase persecutória ou de grandezas, o segundo indicaria como fenômeno de incompatibilidade com as exigências superiores da civilização - um anacronismo palmar, a revivescência de atributos psíquicos remotíssimos". (Cunha, 1901, p.63)
} 
A obra de Lombroso teve uma repercussão imensa tanto no mundo acadêmico como no meio popular e diversos estudiosos brasileiros passaram a tratar as Ciências Criminais através de aspectos de sua obra. Foram criados alguns institutos com enfoque nas teorias lombrosianas como a Sociedade de Antropologia Criminal, Psiquiatria e Medicina Legal (1895), a Sociedade de Medicina Legal e Criminologia (1914) e o Instituto Brasileiro de Criminologia (1931) (Ferreira, 2010, p.57). Alguns teóricos brasileiros foram pioneiros em trabalhos que associavam a criminialidade à raça, tratando esta última como possível pré-disposição ao cometimento de um crime.

O Código Penal de 1940 inspirava-se fortemente em idéias de caráter deterministas, principalmente quanto aos aspectos sociais. A crise política, econômica e social que o Brasil e o mundo vivenciavam, a repressão social e o aumento da criminalidade presidiram à elaboração do $\mathrm{CP}$ - como não poderia deixar de ser, pois a lei penal sempre se faz necessária para o controle social. Nas palavras de Vera Regina Andrade Pereira:

"[...] os resultados da análise teórica e de uma série inumerável de pesquisas empíricas sobre os mecanismos de criminalização tomados em particular e em seu conjunto podem ser condensados em três preposições que constituem a negação radical do mito do Direito Penal como direito igualitário que está na base da ideologia da defesa social. a) O Direito Penal não defende todos e somente os bens essenciais nos quais todos os cidadão estão igualmente interessados e quando castiga as ofensas aos bens essenciais, o faz com intensidade desigual e de modo parcial (fragmentário); b) A lei penal não é igual para todos. O status de criminal é desigualmente distribuído entre os indivíduos; c) $\mathrm{O}$ grau efetivo de tutela e da distribuição do status de criminal é independente da danosidade social das ações e da gravidade das infrações à lei pois estas não constituem as principais variáveis da reação criminalizadora e de sua intensidade" (Andrade, 1997, p. 54-55).

A influência dessas características é inegável em diversos dispositivos da legislação ordinária, como no papel da personalidade e periculosidade do criminoso para quantificação da pena a ser imposta. Os motivos do crime, dispositivo utilizado pelo juiz para fixação da pena-base a ser imposta ao réu, encontram-se presentes no art.59 do Código Penal de 
1940, com redação alterada pela Lei n 7209 , de 11.7 .1984 e apresentam um exemplo da influência supracitada:

\begin{abstract}
Art. 59 - O juiz, atendendo à culpabilidade, aos antecedentes, à conduta social, à personalidade do agente, aos motivos, às circunstâncias e conseqüências do crime, bem como ao comportamento da vítima, estabelecerá, conforme seja necessário e suficiente para reprovação e prevenção do crime:

I - as penas aplicáveis dentre as cominadas

II - a quantidade de pena aplicável, dentro dos limites previstos;

III - o regime inicial de cumprimento da pena privativa de liberdade;

IV - a substituição da pena privativa da liberdade aplicada, por outra espécie de pena, se cabível.
\end{abstract}

Os conceitos de personalidade e de periculosidade criminosas são decorrentes de um processo de transformação daquilo que se define como determinismo. Em um primeiro momento, com Lombroso, as características eram definidas em sua maioria através de aspectos biológicos. Aos poucos, com outros autores como Enrico Ferri ${ }^{25}$, Raffaele Garofalo ${ }^{26}$ e Napoleone Colajanni $^{27}$, as concepções deterministas migram para fatores psicológicos (determinismo moral) e, em seguida, para aspectos de caráter essencialmente sociais, conceituando-se o criminoso dentro dos estereótipos sustentados pelas diferenças socioeconômicas. A associação direta entre crime e pobreza, consagrou os altos indíces de criminalidade e violência

\footnotetext{
${ }^{25}$ Enrico Ferri $(1856$ - 1929) foi um criminologista e um dos primeiro percursores das Escola Italiana de Criminologia Positivista. Além disso, atuava na política em defesesa dos ideais socialistas tentando explicar os índices de crimininalidade a partir de estudos, diferentemente de Lombroso, não decorrentes de patologias individuais. Sua constatação era que existia uma enorme influência dos fenômenos sociais e economicos nos índices de criminalidade e que por isso era necessário um estudo que englobasse estudos antropológicos, naturais (clima ex.) e sociais (opinião pública, moral, religião e etc..).

${ }^{26}$ Raffaele Garofalo (1851 - 1934) foi um criminologista e jurista de descendência italiana, que foi responsável por uma das primeiras aprarições do vocábulo criminologia. Seus estudos concentravam estritamente na seara da psicologia, fazendo-o interpretar os índices de crimininalidade a partir da constatação de que aqueles que cometem crime possuem um déficit na esfera moral e sentimental. Essa afronta a sentimentos básicos e que sustentam a sociedade fez surgir a teoria do crime natural, que definia eses comportamentos como uma mutação psiquíca de caráter hereditário. As conotações atávicas, assim como Lombroso, também tiveram importância no estudo do criminologista.

${ }^{27}$ Napoleone Colajanni (1847 - 1921) também fez parte do grupo de juristas italianos da segunda metade do século XIX que abandonou o republicanismo, passando a ser conhecido como um dos fundadores do Socialismo Siciliano (apesar de ter idéias divergentes do que pregava o Marxismo, considerando-se um Darwinista Social). Teve brilhante carreira política sendo eleito sucessivamente como membro da Câmara dos Deputados Italiana. Era um grande crítico da criminologia biológica determinista de Cesare Lombroso, sendo responsável pela primeira obra cujo termo Criminologia apareceria no título: "La Sociologia Criminale".
} 
como fenômenos de natureza econômica, nos quais há privação de oportunidades, desigualdade social e marginalização. Tal atribuição também foi fundamental para que o crime fosse combatido com mais vigor na áreas excluídas e economicamente desfavorecidas, não atingindo aqueles indivíduos detentores do poder, que quase sempre saiam impunes. A lógica de identificação social era estereotipada, refletindo apenas a posição social e cultural daquele indivíduo na sociedade, o que permitia esconder qualquer tipo de conflito e dominação. Como afirma Zaffaroni:

"O código de 1940 possui uma parte especial ordenada da mesma maneira que apresentava o projeto Galdino Siqueira, ou seja, encabeçada com os delitos contra a pessoa, mas com uma estrutura decididamente neoidealista, própria do código italiano de 1930. É um código rigoroso, rígido, autoritário no seu cunho ideológico, impregnado de 'medidas de segurança' pós-delituosas, que operavam através do sistema 'duplo-binário' ou da 'dupla via'. Através deste sistema de "medidas" e da supressão de toda norma reguladora da pena no concurso real, chegava-se a burlar, dessa forma, a proibição constitucional da pena perpétua. Seu texto corresponde a um 'tecnismo jurídico' autoritário que, com a combinação de penas retributivas e medidas de segurança indeterminadas (própria do Código Rocco), desemboca numa clara deterioração da segurança jurídica e converte-se num instrumento de neutralização de 'indesejáveis', pelas simples deterioração provocada pela institucionalização demasiadamente prolongada". (Zaffaroni, 2011, p. 199)

Na criação do Código Penal Brasileiro de 1940, portanto, encontramse elementos do Positivismo Antropológico voltados à Defesa Social. Cabe salientar que a maior parte dos contraventores nesse momento eram moradores de bairros típicos das classes populares e que na maioria dos processos o que importava não era o ato criminoso em si e sim a condição social de quem cometeu o delito. ${ }^{28}$ Como a maoiria não possuía recursos para contratação de um advogado, uma defesa gratuita era cedida aos indivíduos que exerciam uma função considerada "de bem". Assim, o trabalho passava a ser atestado de boa índole e honestidade.

\footnotetext{
${ }^{28}$ Um exemplo disso é o crime de vadiagem que no Código Penal de 1930 assim era tipificado e que posteriormente com o Código Penal de 1940 foi remetido ao disciplinamento da Lei de Contravenções Penais de 1942: "A vadiagem representa o receptáculo maior, onde se enquadra o "viveiro natural da delinquência" na linguagem dos relatórios policiais. O próprio sistema repressivo constitui este viveiro, formado por uns poucos grandes "malandros" e a massa de pequenos marginais ou desempregados, à beira da indigência [...]" (Fausto, 1984, p.35)
} 


\section{1 - Poder e Ideologia}

O Tribunal do Júri no Brasil como instituição sofreu uma série de mudanças ao longo do tempo, que estão diretamente relacionadas com as mudanças ideológicas e comportamentais da sociedade ao longo de quase dois séculos. Embora o Júri mantenha um universo próprio, ele está totalmente ligado ao fator cultural que move as relações humanas, alcançando diversas significações, atualizando e sendo atualizado pela própria cultura, a moral, a sociedade e a economia. Fazer parte do jogo do Júri, é entender a dinâmica do poder e perceber que as sessões de julgamento podem ser entendidas como um ritual de caráter lúdico, em seu sentido estrito.

O caráter lúdico atribuído ao Júri Popular tem estreitas relações com o conceito de Jogo como elemento cultural ${ }^{29}$. Muitos dos estudos que, até então, que tentaram definir a função do jogo na sociedade partiram do pressuposto que, para além daquela ação, alguma coisa está realmente "em jogo", transcendendo necessidades imediatas e conferindo algum sentido àquele momento. Contudo, este "além" deve alcançar não apenas fatores de ordem biológica e psicológica, mas sobretudo tomar, o jogo como um fator cultural de significações amplas, transformando a realidade e imaginando-a. Trata-se, portanto, de captar esses valores e significados em constante transformação.

O Júri Popular, assim compreendido a partir dessa sistemática do jogo, produz por meio da manipulação das imagens, um entedimento imagético do que seria a realidade. Compreender o ritual do júri como uma instituição que não produz somente significados com o intuito de justificar a absolvição ou a condenação do réu, trazendo significações de todo um sistema de valores e qualificando diversos aspectos da vida fática, implica tomá-lo como uma construção histórica baseada em uma interpretação do

\footnotetext{
29 "O Júri tem um caráter lúdico porque as principais características de qualquer jogo estão nele presentes. Trata-se de uma atividade consciente, exterior à vida habitual e que, enquanto ocorre, absorve os jogadores de maneira intensa" (Schritzmeyer, 2001, p.i)
} 
conceito de ritual. Os estudos socio-antropológicos até o final do século XIX concentravam-se em definir o ritual a partir de comportamentos próprios a um sistema de práticas religiosas ou de magia. A grande mudança na interpretação do ritual ocorre no momento em que se o toma como dando sentido a práticas sociais, por meio de regras constitutivas. $\mathrm{O}$ ritual deixou, assim, de ser visto como tendo somente como escopo a solidariedade social. As alternativas ideológicas ali concernentes, voltadas ou não para manutenção de um determinado status quo, passaram a ser empiricamente observável. Contudo, esse empirismo não permite abarcar as abstrações características do mundo das representações, que remete ao mundo das significações. É justamente no momento em que se instala o social no simbólico, que a realidade social aparece como um sistema de significações. Assim, os rituais passaram a ser observados como uma "forma privilegiada de comunicação, de envio e recepção de mensagens organizadas através de códigos passíveis de serem decifrados por antropólogos e outros cientistas sociais" (Schritzmeyer, 2012, p.136).

No caso do Júri, as histórias sociais são contadas dentro de um processo ritualístico, no qual se concentra a produção de significados justificando sua existência, forma e organização. A produção desses significados está relacionada com as narrativas apresentadas no Júri que, se mal elaboradas, “...ainda que os jogadores permaneçam confinados em um plenário que os isole do mundo externo, eles não chegarão ao fundamento de suas próprias ações..." (Schritzmeyer, 2012, p.60). Em outras palavras, utilizam-se diversos artíficios, de modo que as circunstâncias definam se o poder de matar é legítimo ou não; mas se mal elaborados, não será construído nem será negada a legitimidade das ações do réu, de tal modo que não fique claro o entendimento acerca de quais valores da vida cotidiana estruturam esse tipo de legitimação. Todos os participantes sejam eles jurados, promotores ou réus - participamdesse "drama da vida" (Schritzmeyer, 2012). As abstrações e materialidades se confundem e se completam dentro desse ritual, pois as regras do jogo do Júri também fazem 
parte das regras da vida social. A importância dessa dinâmica tange justamente ao alcance que as decisões podem ter no sistema de valores e sentimentos daqueles que julgam. A palavra final do juiz - seja o réu absolvido ou não - transmite aquilo que seria legalmente hegemônico, pois os jurados por decisão de sua maioria assim definiram. A "essência social" transmitida através dos rituais do júri, além de estar em constante processo de re-significação, representa as relações estruturais de poder, seja por meio do ato ritualístico em si (linguagens, movimentos e posicionamentos próprios de cada ator dentro do tribunal), seja por meio das abstrações trazidas pelos jurados dentro daquele universo próprio.

Como visto, o Brasil apresenta em seu processo de codificações de leis penais, uma grande influência do Positivismo Criminológico Clássico, em especial da Escola Italiana. A criação do direito material e processual na seara penal, foi promovido pelas estruturas de poder e instituições que eram legitimadas a propor os caminhos a serem seguidos pela sociedade. Apesar das variáveis que cada jurado pode apresentar, que são estritamente individuais e de suma importância na observação dos promotores e advogados, o pensamento discriminatório e excludente ainda sobrevive em boa parte dos corpos sociais. O objeto de defesa ou da própria promotoria será muitas vezes a desconstrução ou a manutenção desse modelo de "poder" apresentado nos dramas do Júri. Em grande parte, os jurados são cidadãos comuns, usualmente de classe média, que representam em boa parte aquilo que podemos denominar de "senso comum", referente à criminalidade e ao funcionamento social.

Uma comparação importante é a relação entre Poder e drama. Não à toa, o realismo político de Maquiavel influenciou decisivamente a obra de Shakespeare, inclusive servindo-lhe a construir personagens, como Ricardo III. A arte de governar implica o emprego de técnicas dramáticas assim como no teatro, conferindo um novo sentido à ação realizada em nome do poder. Tal sentido está inexoravelmente ligado à percepção de que existe uma estreita relação entre a arte de governar e a necessidade de 
compreensão da natureza humana. Como afirma Georges Balandier: "...o poder está sempre a serviço de uma estrutura social que não se pode manter somente pela intervenção do 'costume' ou da lei, por uma espécie de conformidade automática às regras." (Balandier, 1969, p.35). O poder não se consubstancia apenas com leis morais ou jurídicas, ou mesmo pelos costumes da coletividade, ele necessita de um constante processo de reafirmação e legitimação.

Embora o jogo do Júri preveja a apresentação de teses conflitivas da promotoria e da defesa - com pouca frequência os conflitos sociais que estão na base dos crimes julgados são trazidos à baila. I.e., não ficam evidentes as desigualdades e a própria hierarquia social, reforçando-se sua legitimidade como "coisas naturais". O poder está justamente na capacidade que se tem em ritualizar os conflitos, de modo que se conserve o bom estado social ou que se adaptem as mudanças em prol da manutenção da ordem. Balandier esclarece: "Recorrendo a uma fórmula sintética, definirse-á o poder como resultante, para toda a sociedade, da necessidade de lutar contra a entropia e a ameaça de desordem [...]." (Balandier, 1969, p.36).

$\mathrm{Na}$ esteira dessa análise, podemos entender a força que existe nos resultados dos julgamentos no Tribunal do Júri a partir da forte relação de causa e efeito que existe entre as classes ou camadas que julgam e as que são julgadas. O número maior de condenações entre aqueles considerados inadequados ao modelo de comportamento social ímplicito nos códigos, pode ser explicado devido ao processo de elitização do corpo de jurados. Cabe salientar que as decisões emanados pela instituição do Júri, não correspondem mecanicamente a nenhum estrato social. Pode ser que em determinado momento, a introjeção de outros valores ideológicos façam um jurado de camadas inferiores pensar e ter atitudes como aqueles de classe superior - e vice-versa. Nas palavras do jurista italiano Alessandro Baratta:

"Pesquisas empíricas colocaram em relevo as diferenças de atitude emotiva e valorativa dos juízes, em face de indíviduos que pertencem a classes sociais diversas. Isto leva os juízes, inconscientemente, a tendências de juízos diferentes conforme a posição social dos acusados, e relativas tanto à apreciação do 
elemento subjetivo do delito (dolo, culpa), como ao caráter sintomático do delito em face da personalidade (prognose sobre a conduta futura do acusado) e, portanto, a individualização e a mensuração da pena destes pontos de vista. A distribuição das definições criminais se ressente, por isso, de modo particular, como efeito da diferenciação social. Em geral, pode-se afirmar que existe uma tendência por parte dos júizes de esperar um comportamento conforme à lei dos indivíduos que pertencem aos estratos médios e superiores; o inverso ocorre com os indivíduos proveninentes dos estratos inferiores" (Baratta, 2004, p.186 e 187 tradução minha).

A idéia, portanto, é a de que existem pessoas engajadas na negação da ordem social, incapazes de cumprir as normas e usufruir da vida coletiva, apesar das oportunidades estarem disponíveis. A estrutura social do país está vinculada a esses aspectos hierarquizantes, sendo reforçada a partir de mecanismos que excluem ou incluem cidadãos. Podemos citar como exemplo, o grau de escolaridade e a ocupação profissional, que foram quesitos utilizados para as reformas da legislação penal na primeira metada do século XX. Como sugere Streck, o imaginário social dominante difundiu a ideia de uma "índole e educação de nosso povo que em geral não tem muito intenso o sentimento de respeito à lei e ao princípio de autoridade" (Neder, 1995, p. 50 e 51 apud Streck, 2001, p.133). Esse imaginário construiu-se com base em uma concepção das diferenças sociais hierárquicas, que não se ateve aos motivos mesmos que deram origem a tais diferenças. Como a afirma Streck, isso faz com que os fatos sociais surjam "muitas da vezes como 'naturais', a-históricos, congelados, sem origem definida e, por conseguinte, 'incontenstáveis'" (Streck, 2001, p.133) Apesar de alguns autores entenderem que a ideologia de classe não é um fator relevante para o deslinde do julgamento (a índole e as características da comunidade em lidar com o delito e seus autores seria o ponto primordial para o resultado do julgamento), os estereótipos e preconceitos, se acrescidos do senso comum (fomentado por essa matriz ideológica), tenderão desfavoráveis aos indíviduos pertencentes aos estratos sociais inferiores. Assim, nas palavras de Marilena Chauí:

" (...) como forma do exercício da dominação de classe, a eficácia da ideologia depende de sua capacidade para produzir um imaginário coletivo em cujo o 
interior os indivíduos possam localizar-se, identificar-se e, pelo autoreconhecimento assim obtido, legitimar involuntariamente a divisão social. Portanto, a eficácia ideológica depende da interiorização do "corpus" imaginário, de sua identificação com o próprio real e especialmente de sua capacidade para permanecer invisível. Pode-se dizer que um ideologia é hegemônica quando não precisa mostrar-se, quando não necessita de signos visíveis para se impor, mas flui espontaneamente como verdade igualmente aceita por todos" (Chaui, 1980, p.25) 


\section{CAPÍTULO 3 - Performance, Teatro e Retórica do Poder}

A análise meramente socio-antropológica dos aspectos que influenciam o Júri Popular não nos permite prever automaticamente o desfecho em um julgamento no tribunal. A praxis jurídica exige dentro desse modelo, além de uma ótima percepção dos conceitos teóricos e valorativos, uma hermenêutica capaz de interpretar os discursos específicos que estão por trás das convicções dos jurados. Independentemente das concepções políticas, sociais e econômicas de cada um, é necessário que os discursos proferidos pelos defensores e promotores sejam dotados de uma retórica capaz de persuadir os membros do corpo de jurados - o que é uma tarefa extremamente difícil.

As soluções das questões reais, presentes dentro da seara na qual o direito será o solucionador dos conflitos, não podem deixar de usar como parâmetro os fundamentos partilhados por uma comunidade jurídica. Assim, esses parâmetros de pré-compreensão (tradição e história) serão essenciais para horizontalizar os pensamentos daqueles que querem compreender o universo fenomênico: "O horizonte de interpretação pressupõem subjetivações e sensibilidades próprias de indivíduo em relação com a sua cultura e não somente a uma concepção normativa fixa e positiva" (Oliveira \& Ataídes, [2012], p.3). Assim, sabendo que o Direito não pode ser reduzido a uma exclusiva elaboração abstrata, a prática jurídica deve ter sua hermenêutica relacionada com o universo artístico.

Os contextos aos quais o Direito pode ser relacionado são de diversas ordens. Aqui, interessa-nos observá-lo a partir do prisma da performance. Ronald Dworkin observaria o quanto é importante por parte daqueles que fazem parte desse universo, o estudo de técnicas de interpretação, tanto artísticas como literárias, assemelhando-se as funções de um diretor de teatro, já que deve saber os elementos aplicáveis na preparação, ensaio e apresentação da trama jurídica (Oliveira \& Ataídes, [2012], p.4). Já o autor 
José Calvo Gonzalez atribui ainda outro elemento essencial na tarefa interpretativa do direito: os gestos. Este autor define que:

\begin{abstract}
"[...] se a justiça é relato e narrativa, revela-se por miríade de formas, que transitam de expressão escrita para energia gestual [...] uma quantidade exuberante de gestos presentes na performance jurídica: maneios cartesianos, lânguidos, involuntários, tiques, espasmódicos, arrogantes, humildes, irascíveis, o martelo do magistrado que apela pelo silêncio, o dedo em riste do acusador, o olhar reverente do réu, gestos e expressões em suma persuasivos e convincentes". (Calvo, 2003, p. 13, apud Oliveira \& Ataídes, [2012], p.3)
\end{abstract}

A palavra performance usualmente utilizada para referir-se ao desempenho em práticas esportivas, ganhou grande generalidade e vem sendo empregada nos mais diversos domínios, definindo inclusive, a partir dos anos 1970, um campo artístico, o das chamadas performing arts (artes da performance). $\mathrm{O}$ termo supera velhas dicotomias como aquela entre arte e vida, permitindo aplicar-se a vários campos de atuação, inclusive - e isso é o que nos interessa aqui - à atuação de advogados em um tribunal. Portanto, pode-se dizer que o ritual do Júri também é um ritual performático. A dinamicidade e expressividade da performance presentes no Direito, não tange ao resultado em si, e sim ao processo que se dá a partir de uma construção ritualística. Tanto na língua inglesa, to perform, como na francesa, parfounir, a performance significa um processo de agir, dar um sentido a determinada ação (Oliveira \& Ataídes, [2012], p.4-5).

Parece-nos desejável fazer a crítica à falta de oxigenação que existe na dogmática jurídica, que cristalizou métodos e modelos de pensar e agir encerrando-se no universo estrito do direito. Se já existe a constatação de que o desenvolvimento histórico e social do ser humano se deu a partir da criação de signos, sinais e símbolos, que formam a construção imaginária dos elementos essenciais à formação da sociedade, esta notável ritualização, não poderia ser visualizada sem se atentar para o espírito performático o qual ela é delimitada. A performance:

" [...] os elementos performáticos, contribuem de forma decisiva na delimitação da identidade de determinado sujeito ou coletividade, sobretudo por apresentar 
uma dinamicidade vinculada ao presente e que, apesar do mergulho no passado, usa este como meio para expressão de fatos do presente. Isto porque a performance reproduz a vida ao vivo, representando através do presente (representação)." (Oliveira \& Ataídes, [2012], p.6)

$\mathrm{Na}$ esteira dessa tentativa de análise da dogmática jurídica, longe dos holofotes do positivismo e do formalismo, a atribuição performática dada ao Direito, aproxima-se da teatrocracia, termo cunhado pelo diretor e dratamaturgo russo Nicolau Evreinov. ${ }^{30}$ Inspirado no conceito de Jogo de Huizinga, Evreinov entendia o teatro como um espaço lúdico, no qual era necessário delimitar um espaço e um tempo próprios, a fim de que as representações da vida cotidiana ali inseridas pudessem escapar da existência ordinária, entediante e cotidiana ${ }^{31}$, transgredindo assim as normas do estado e da sociedade. A representação, aqui, não é uma imitação, como acontece no teatro naturalista, não existindo, portanto, limites à ilusão teatral.

Esse modelo de performance teatral influenciou, e muito, o poder político. Um conjunto enorme de técnicas destinadas a produzir ilusões, camuflar a realidade, transformar o real no imaginário, são utilizadas para a validação das aparências disfarçadas de veracidade. A teatralidade é chave do poder, e não, como anteriormente já foi dito, a dominação brutal ou mesmo justificação racional. Balandier explicita esse conjunto de técnicas teatrais por meio de um exemplo praticado pelo monge domenicano Savonarola em Florença, no final do século XV:

"(...) sua pregação transforma o imaginário em presença. (...) A mecânica empregada para produzir efeitos é a máquina da oratória. O poder adquirido é teatral na acepção mais imediata do termo. (...) Florença é então submetida a uma 'ditadura da voz'. É com esse desempenho que o imaginário e a ideologia se tornam ilusões realizadas" (Balandier, 1982, p. 6, apud Shritzmeyer, 2012, p.177)

\footnotetext{
${ }^{30}$ Evreinov exerceu uma importante influência sobre o dramaturgo e escritor irlândes Samuel Beckett (1906-1989), considerado um dos últimos modernistas e fundador do conhecido "Teatro do Absurdo". Beckett tinha uma visão pessimista a cerca do fenômeno humano. Ganhou o Nobel de literatura em 1969 e tem como uma das sua principais obras "Esperando Godot".

31 O pessimismo metafísico, termo empregado por Nietzsche e mais radicalmente por Shopenhauer, em uma definição do conceito tomado genericamente, poderia significar a predominância/supremacia de aspectos maus de ordem moral e metafísica (existência), sobre aqueles tido como bons ou positivos.
} 
No júri popular, essa teatralidade é essencial, mesmo que a ratio decidendi dos jurados esteja vinculada às provas dos autos, sendo de alguma forma ligada aos fatos que realmente aconteceram. A ilusão teatral no júri leva seus personagens a aparecerem como uma espécie de porta vozes de valores universais. É justamente nesse ponto que podemos entender o quão legítimo pode se tornar esse modelo de julgamento, que apesar de apresentar uma série de desigualdades entre os que julgam e os que são julgados, promove aquilo que seria uma justiça superior, na qual duelam o "bem" e o "mal", ou mesmo o "perdão" e a "punição". O fato imputado em si perde valor diante das dramatizações que, muitas das vezes, tornam-se o fator preponderante para a condenação ou a absolvição; i.e, permitem convencer o jurado de que certas vidas foram ceifadas de forma legítima, enquanto outras não. ${ }^{32}$

A principal fuga dessa realidade fática se consubstancia a partir daquilo que Balandier denomina "linguagem do poder"; ou seja, não há somente um aplicabilidade imediata do resultado quanto a uma punição ao dano social causado por um homícidio, pois o resultado reflete uma idéia de justiça social por meio da qual a sociedade passa a ser alertada de que este delito não se faz impunemente. Os efeitos precisos desse tipo de linguagem extrapolam, portanto, o momento de julgamento, apontando valores sociais relevantes, como por exemplo: "(...) o que deve orientar este julgamento são os principios morais que regem os homens de bem (...)"; ou "(...) o que aconteceu é um retrato da degradação humana (...)"; ou ainda "(...) este caso evidencia que o progresso da humanidade não se dá de maneira uniforme, pois há retrocessos (...)" (Shritzmeyer, 2012, p.182). Um outra demonstração dessa relação de poder dentro dessa sistemática é o fato de serem proibidos quaisquer comentários entre os jurados acerca do

\footnotetext{
${ }^{32} \mathrm{Um}$ dos institutos que pode levar ao excludente de culpabilidade e que, portanto, poderia justificar o crime de homícidio é a legítima defesa. Como preceituado pelo Art.25 do Código Penal: "Entende-se como legítima defesa quem, usando moderadamente dos meios necessários, repele injusta agressão, atual ou iminente, a direito seu ou de outrem".
} 
julgamento nos intervaloss da sessões, havendo especial apreço pelo sigilo e pelo silêncio.

O palco e a platéia também elucidam por completo o lugar dos "governantes" e dos "governados", como também a linguagem por eles empregadas no tratamento de uns com os outros. Os defensores e membros do Ministério Público se dirigem entre eles com cumprimentos e saudações particulares, o que também ajuda a legitimar suas imagens públicas e criar uma certa hierarquia a ser seguida dentro daquele espaço. Além disso, a utilização de jargão de caráter técnico-científico, em especial na demonstração das "provas materias", apesar de muitas das vezes ininteligível para a maior parte dos jurados, transmite a idéia de que a tecnicidade e a cientificidade são recursos capaz de revelar as "verdades" em jogo.

\section{1 - A montagem do Palco, linguagem e gestualidade}

As sessões do Tribunal do Júri, por serem apresentadas numa instituição de controle de criminalidade, são dotadas de um script obrigatório, que deve ser seguido de modo a que não haja inversão dos procedimentos, o que poderia, de um lado, ferir os próprios dispositivos legais e, de outro, inviabilizar os direitos inerentes à acusação e, principalmente, à defesa. Em decisão do Supremo Tribunal de Justiça em 2011, de relatoria do Min. Gilson Dipp (Quinta Turma) ${ }^{33}$, não há que se falar em eloquência acusatória se na decisão de pronúncia não foi feito nenhum excesso de linguagem capaz de criar um juízo conclusivo sobre a participação do réu nos fatos imputados ${ }^{34}$. Quando da pronúncia do réu, o juizo de admissibilidade é uma verificação dos indícios de autoria e

\footnotetext{
${ }^{33}$ STJ, HC n. 212175/SP - Rel. Min. Gilson Dipp, DJU 2011

34 "O reconhecimento do vício do excesso de linguagem reclama a verificação do uso de frases, afirmações ou assertivas que traduzam verdadeiro juízo conclusivo sobre a participação do acusado, de maneira a influenciar os jurados futuramente no julgamento a ser realizado. (...) Vedase, portanto, a eloquência acusatória, por extrapolar o mero juízo de admissibilidade da acusação, invadindo a competência do Conselho de Sentença, hipótese, ao que parece, inocorrente na espécie, em que não houve esse juízo antecipado" (Min. Felix Fischer no julgamento da liminar do HC 212175/SP)
} 
materialidade, que acarreterá futuro julgamento do réu perante o Tribunal do Júri. $\mathrm{O}$ uso da palavras aqui é restrito, podendo acarretar no desentranhamento da pronúncia, caso houver vício de linguagem, e, portanto, um novo juízo de admissibilidade.

A existência de um espaço próprio, uma espécie de isolamento artificial, é marca presente na maior parte dos rituais de caráter lúdico ou que almejam algum fim sagrado. A consecução do direito no Tribunal do Júri supõem um palco no qual se produz um tempo e espaço próprios, regidos por regras constitutivas específicas. Assim como no teatro, existe uma diferença clara entre quem atua e quem assiste, bem como marcações espaciais de modo que o ator (personagem do júri) saiba como se comportar quando está diante de uma peça (um julgamento). No Júri popular, a assistência (composta em sua maioria por estagiários, família do réu, curiosos, entre outros) representaria o lado profano, em comparação com as posições do juíz, acusadores, defensores, réu e jurados, que estariam em posição especial e de uma certa forma "sagrada". A própria vestimenta, com suas togas, definiria essa separação entre os "comuns" e personagens "especiais". Interessante observar, que são justamente os jurados que representam essa passagem entre o leigo e o saber técnico, demonstrando que a noção de "status" aqui é uma das virtudes mais almejadas, mesmo que indiretamente, por aqueles jurados que nesse momento fazem parte de um grupo seleto de pessoas.

Dividido em duas principais salas, o plenário e a sala dos jurados, a separação espacial do tribunal corrobora a tese de que existe um diferença clara entre o mundo do ritual e o mundo cotidiano. E mais além, se entendido o plenário como uma divisão entre dois ambientes diversos, o qual delimitaria o lugar da assistência, separado por uma linha bem demarcada dos demais participantes, há de se ater à semelhança que existe entre as sessões plenárias e a gramática espacial dos cultos da tradicional igreja católica apostólica romana. 


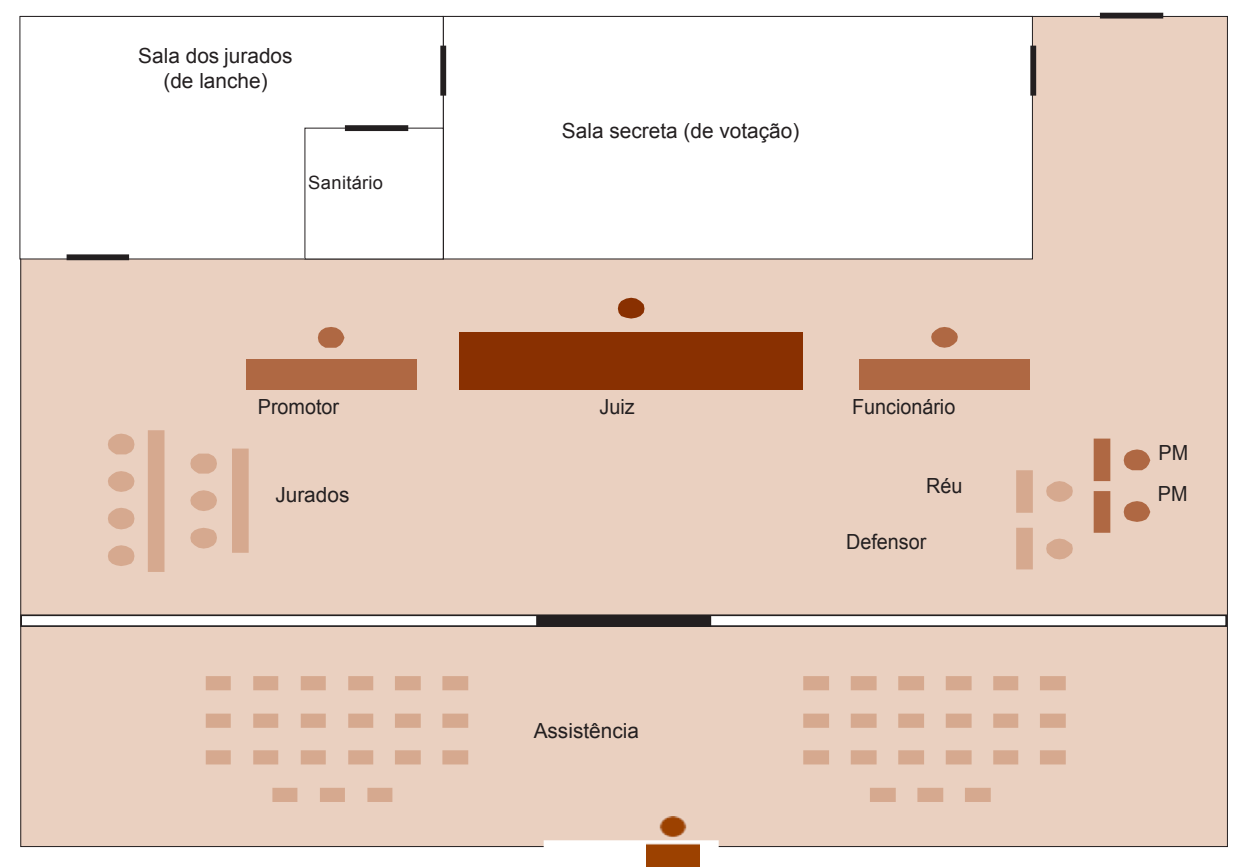

Figura 1. Plenário ${ }^{35}$

Esta, também apresenta uma tríplice divisão, configurando o fundo do altar como lugar íntimo e secreto de padres e iniciados, o meio do altar como o lugar representado pelos sacerdotes, tendo sua mesa disposta ao centro, e, por último, as cadeiras laterais onde permanecem os demais participantes, sendo eles coroinhas, fiéis ou ainda outros sacerdotes (Schritzmeyer, 2012, p.66). A grande diferença tange ao uso espacial da linguagem, que apresenta um outro eixo de apresentação em relação ao Júri Popular. As arguições são apresentadas em um eixo horizontal $(\longleftrightarrow)$, com o intuito de convencer os jurados das suas alegações e outro vertical $(\uparrow \downarrow)$, aquele mais utilizado pelo promotor, visto que deve se levantar de seu posto ao lado do juiz e se colocar entre réu e jurados.

Nas palavras da doutora Ana Lúcia Shritzmeyer:

"A maior diferença entre o que se passa nos espaços do plenário e de igrejas católicas talvez seja que nestas o eixo imaginário pelo qual flui a linguagem persuasiva é, principalmente, o que liga sacerdote a fiéis - o vertical $(\uparrow \downarrow)$. Antigamente, no momento do sermão, da "conversa" mais direta e informal entre

\footnotetext{
${ }^{35}$ Shritzmeyer, 2012, p.62
} 
sacerdote e fiéis, o pregador saía do altar e ocupava o púlpito, situado em um ponto mais alto, porém inserido no espaço reservado aos fiéis". (Shritzmeyer, 2012, p.67)

Quanto ao uso da linguagem, a Retórica, abarcada pelo trinômio demonstração-argumentação-persuasão ${ }^{36}$, assim como definia Aristóteles (e também Perelman, aproximando a velha da nova retórica), é o modelo a ser empregado no convencimento dos jurados no seio de um processo jurídico argumentativo. O jogo da persuasão deve estar estruturado no lógos, sendo compatível com um sistema de normas e princípios, mas longe de ser cartesiano, deve apresentar dinamicidade, criatividade e, sobretudo, atender aos interesses e anseios sociais. "O positivismo lógico, cujo raciocínio é constringente e infenso a qualquer tipo de constestação" (Henriques, 2008, p.3) deve ser posto de lado, visto que o Direito é fomentado pela discussão, sugestões e negociações, determinando ser caráter retórico. Cabe salientar que é, por isso, que se tem abandonado o brocardo "lógica júridica" ou mesmo "racícionio jurídico", passando a interpretá-lo a partir de outros axiomas, definindo-o como "pensamento jurídico". Portanto, a razão normativa nunca atingirá a realidade humana por completo, já que o humano é um ser contingente (ens ab alio), dependente do tempo e das paixões. De acordo com Antonio Henriques, em "Argumentação e Discurso Jurídico", Perelman esqueceu de mencionar a função das paixões (páthos) no processo argumentativo de persuasão.

A parte denominada argumentativa na Retórica é, justamente, a Dialética, já que por ser de caráter especulativo, que tange ao estudo dos argumentos e não à sua aceitabilidade (função Retórica), ela deve se restringir a solucionar as divergências a partir das regras e disputas já regulamentadas.

\footnotetext{
${ }^{36}$ Alguns outros autores da Nova Retórica como Pascal Quignard, estudioso da retórica especulativa de Marco Cornelio Frontão, professor de retórica e preceptor do imperador romano Marco Aurélio, estruturam esse modelo a partir do binômio demonstração-persuasão. A necessidade de se estruturar a partir do trinômio, é primordial já que :"Tal jogo desenvolve-se entre seres sociais que interagem por meio de uma linguagem portadora de argumentatividade, inscrita na língua. Tal interação é e confere à Retórica um caráter pragmático" (Henriques, 2008, p.13)
} 
"São elementos indissociáveis no processo de persuasão no sentido de que ambas tratam de verossímel (eikos), do que parece ser possível, e se contrapõem à sofística, que lida com o inverossímil, jogando com a aparência ou simulacro de raciocínio. Ademais ambas servem-se da indução e da dedução, além de outros pontos em comum, como o processo dialógico" (Henriques, 2008, p. 39-40)

No júri popular, enquanto espaço cênico, essa carga argumentativa deve ser explorada com mais veemência, transformando os discursos em verdadeiros encantamentos, capazes de impressionar e comover o corpo de jurados. Além da linguagem, os gestos e a percepção destes, são imprescindíveis ao bom resultado almejado pela acusação e pela defesa. Durante o momento em que há a inquirição das testemunhas, por exemplo, é essencial a observação de quais perguntas e respostas realmente chamaram a atenção dos jurados. A maximização do contato visual com aqueles que serão os destinatários da palavra decisória, permitindo um melhor percepção dos aspectos não-verbais da interação em cena, deve possibilitar uma avaliação mais específica sobre quais elementos persuasivos serão mais potentes que outros. Alguns advogados (defensores) e promotores, em sua maoiria no ínicio de carreira, preferem utilizar anotações nas sustentações orais de modo que nada seja deixado de lado ou esquecido. O diretor Elliot Wilcox, editor do site TrialTheater, afirma que dirigir a atenção para as anotações durante a inquirição de uma testemunha, além de ser rude com os jurados, demonstra um certo desinteresse com aquilo que a testemunha está falando, atribuindo quase nenhum valor as respostas dadas pela mesma. ${ }^{37}$ Além disso, quanto ao campo de projeção das perguntas a serem utilizadas com as testemunhas, estreitar o modelo de pergunta, ou seja, não questionar de forma ampla como por exemplo, "E o que aconteceu a seguir?", também restringe o campo da resposta a ser dada, não permitindo o seguimento linear da história que o defensor , advogado ou promotor, pretende naquele momento.

$\mathrm{Na}$ percepção de alguns acusadores e defensores, o contato visual com os jurados é, a maneira mais fácil de conseguir-se a atenção dos

\footnotetext{
${ }^{37} \mathrm{O}$ site pode ser acessado no endereço http://trialtheater.com/
} 
mesmos, de modo que possam aderir à argumentação. Contudo, as expressões faciais de aprovação ou recusa dos argumentos apresentados, é de difícil constatação. $\mathrm{Na}$ fala de um promotor:

" (...) é só um modo de acompanhar. Eles levam muito a sério o fato de não poderem se expressar o que estão sentindo, embora, às vezes, deixem escapar alguns sinais de agrado ou desagrado. Mas é a gente que tem de imaginar o que eles pensam e se antecipar (...) Certas frases eu falo olhando para as juradas e outras para os jurados. Não é à toa que eu, quando digo certas coisas, fico ao lado de uma dona de casa e, depois, vou para o lado do jovem empresário que quer subir na vida (...) Mas a gente se engana, porque os jurados jogam com essa história de incomunicabilidade e do sigilo dos votos. Esse é o poder deles." (Shritzmeyer, 2012, p.129)

Portanto, a metodologia a ser adotada no Júri popular deve ser dinâmica, utilizando um arsenal de técnicas, cada qual apropriada para um determinado momento. Da mesma forma, no teatro, o ator tem de estar em constante mutação, adaptando-se às circunstâncias de cada peça e aperfeiçoando cada vez mais a sua própria técnica. Stanislawski, em seu sistema de atuação, muitas vezes confundido com o método de interpretação de Lee Strasberg ${ }^{38}$, define que a interpretação deve ser a mais real possível, utilizando-se com muita cautela a memória emotiva. $\mathrm{O}$ ator deve introjetar de tal forma o papel que deverá exercer naquele momento, que suas ações passam a ser realizadas sem um processo de racionalização daqueles movimentos, sem ser necessário refletir acerca do que fazer. Não há necessidade de se adentrar ao mundo perigoso das memórias, já que muita das vezes o o ator pode não conseguir mais disassociar a realidade da atuação. Em uma das passagens de "A construção da personagem", Stanislawski se dirige para um dos seus alunos e afirma:

\footnotetext{
${ }^{38}$ A atriz americana e aclamada professora de técnicas de atuação, Stella Adler (1901-1992), após uma passagem pelo teatro russo onde lecionava com Stanislawski, retornou aos EUA e tentou difundir o sistema adotado pelo diretor russo, por acreditar que muito de seus ensinamentos estavam sendo distorcidos pelas escolas de atuação, como a do ator e diretor, Lee Strasberg. A grande diferença dos dois modelos de interpretação, consiste no uso da memória emotiva. Lee entendia que as sensações pessoais, ou seja, as experiências vividas pelo ator, tinham de ser trazidas para dentro do palco, enquanto o método de Stanislawski defendia o recurso à própria imaginação do ator para a caracterização física e emocional do personagem.
} 
"(...) Quando tiverem desenvolvido força de vontade em seus movimentos e ações corpóreas acharão mais fácil transferi-la para a vivência do seu papel e aprenderão a se entregar, sem refletir, instantânea e totalmente, ao poder da intuição e da inspiração (...) representando, nenhum gesto deve ser feito apenas em função do próprio gesto. Seus movimentos devem ter sempre um propósito e estar sempre relacionados com o conteúdo de seu papel. A ação significativa e produtiva exclui automaticamente a afetação, as poses e outros resultados assim perigosos." (Stanislawski, 1986, p.63-68)

\section{2 - Regras Procedimentais e a Lei 11.689/08}

As marcações teatrais, que serão de maior e menor intensidade dependendo da liberdade que cada diretor dará aos seus atores, podem ser identificadas no jogos do Júri, como regras procedimentais, já que são praticamente os únicas elementos de cena que restringem de certa forma a liberdade de cada personagem. Essa regras, porém, não possuem qualquer margem para alteração, já que estão instituídas por Lei Ordinária, aqui denominada Código de Processo Penal. Cabe, portanto, relembrar de forma breve a esquematização dos debates adotados durante o processo no Tribunal e também as mudanças promovidas pela Lei 11.689/08, que alterou de forma sensível a ordem procedimental.

A primeira dessas alterações tange justamente à idade mínima para se tornar jurado. Anteriomente à Lei de 2008, a idade era de 21 anos, o que poderia comprometer o desfecho decisório, já que a maioria das críticas, tangenciavam ao fato de não se poder constatar a idoneidade em um cidadão tão novo. Com a mudança, porém, a idade foi ainda mais reduzida, passando para 18 anos apenas, o que certamente poderá diminuir a qualidade das decisões. Contudo, deve abrir margem para um número maior de interessados, principalmente universitários. Cabe ressaltar, que já no advento da nova lei, algumas decisões continuaram a ser anuladas em decorrência da presença de jurado menor de 21 anos, alegando-se através do príncipio do prejuízo, a nulidade do julgamento. Em sede recursal, após interposta apelação, a qual foi dada provimento pelo tribunal a quo, o Ministério Público alegou, que por não haver influência do resultado, não 
há que se falar em prejuízo. O voto da Eminente Relatora, Min. Maria Thereza de Assis Moura:

"(...) o acórdão consignou que o prejuízo reclamado para a verificação da nulidade, no caso, estava na resposta ao $16^{\circ}$ quesito, último, por sinal, pelo qual foi inquirido dos jurados se o réu teria confessado espontaneamente a prática do crime (...) Ao contrário, é de se observar que a tese em favor do Recorrido foi a legítima defesa, ou o homicídio privilegiado, em face da qual se pode construir no íntimo dos jurados uma situação de negação do fato criminoso. E isso não tem nada que ver com a presença da jurada menor de 21 anos, que fora aceita pela defesa antes do julgamento. Reafirme-se: a confissão espontânea era tema de somenos importância para o contexto da apreensão dos fatos submetidos ao Tribunal Júri, portanto, não pode levar, por si só, ao sugerido prejuízo à defesa" 39

A segunda alteração a ser comentada, é a reunião do juízo de admissibilidade (406 a 412 do CPP), passando a disposição dos atos processuais a uma audiência única, tendo em vista os princípios da celeridade processual, já que havia muitas críticas em torno da morosidade excessiva do juízo de admissibilidade. A nova lei processual, no que tange a esse aspecto específico, assemelha-se ao que disciplina o Art.81 da Lei 9.099/99 ${ }^{40}$, que além de celeridade, implica uma maior observância aos preceitos constitucionais da ampla defesa. A conclusão deverá constar no prazo máximo de 90 dias (Art.412). Esse prazo pode ser dilatado devido às circunstâncias de cada fato imputado, complexidade do caso, multiplicidade do réus, entre outros fatores. O art.411 define o procedimento da seguinte forma:

\begin{abstract}
Art.411. Na audiência de instrução, procederse-á à tomada de declarações do ofendido, se possível, à inquiração das testemunhas arroladas pela acusação e pela defesa, nesta ordem, bem como aos esclarecimentos dos peritos, às acareações e ao reconhecimento de pessoas e coisas, interrogando-se, em seguida o acusado e procedendo-se o debate.
\end{abstract}

\footnotetext{
${ }^{39}$ REsp 688.199/DF, Rel. Min. Maria Thereza de Assis Moura, 17/11/2009

40" Aberta a audiência, será dada a palavra ao defensor para responder à acusação, após o que o Juiz receberá, ou não, a denúncia ou queixa; havendo recebimento, serão ouvidas a vítima e as testemunhas de acusação e defesa, interrogando-se a seguir o acusado, se presente, passando-se imediatamente aos debates orais e à prolação da sentença" (Art.81, caput, Lei 9.099/95)
} 
$\mathrm{Na}$ pronúncia do réu, as modificações foram significativas, não decretando-se mais a prisão de forma automática após o prosseguimento da denúncia. A prisão ex lege, ausente de fundamentação, foi declarada inconstitucional motivando uma série de mudanças, implementando as diretrizes da própria Carta Constitucional de 1988, dentro os quais os princípios de não-culpabilidade ou presunção de inocência. De acordo com a nova lei, a prisão só será cabível quando preenchidos os requisitos da prisão preventiva, diposto no Art.312 do CPP. Nas palavras do relator, Min. Ricardo Lewandowski:

"(...) tivera sua custódia decretada por ocasião da sentença de pronúncia. Asseverou-se que a segregação cautelar decorrente de pronúncia deve estar pautada em pelo menos um dos requisitos dispostos no art. 312 do CPP e que, no caso, o decreto prisional estaria lastreado apenas no fato de o paciente possuir maus antecedentes. Dessa forma, reputou-se inexistir qualquer elemento fático concreto apto a justificar a medida constritiva. Acrescentou-se que, com o advento da Lei 11.689/2008, tratando-se de réu solto, o juiz somente pode ordenar a sua prisão, quando inequivocamente presentes os já aludidos pressupostos do art. 312 do CPP, não mais subsistindo, para tanto, a análise isolada dos antecedentes do acusado (CPP, art. 413, $3^{\circ}$ ). (...) Consignou-se que, com a reforma do CPP pela referida Lei 11.689/2008, o art. 585 do CPP encontrar-se-ia implicitamente revogado, uma vez que o réu somente deve se recolher ao cárcere se o magistrado assim entender necessário e desde que de modo motivado" ${ }^{41}$

As principais mudanças foram realizadas na primeira fase, mas cabe ressaltar duas delas que se aplicam ao réu que já se encontra pronunciado. A primeira é o fim da necessidade de apresentação ao juiz e aos jurados ${ }^{42}$ pelo Ministério Público ou pelo querelante, do libelo acusatório. O libelo era o documento que continha todas as circunstâncias qualificativas do crime, e que dificultava a celeridade do processo no Tribunal, já que existiam diversos requisitos legais a serem observados para sua constituição, muitas das vezes tornando-se fonte inesgotável de nulidades. Porém, em sentido contrária, o advogado Paulo Rangel afirma: "A supressão do libelo, pela reforma, não trará agilidade nenhuma ao processo, mas sim nulidades, pois caberá ao juiz estabelecer os limites da acusação (...) Juiz não acusa"

\footnotetext{
${ }^{41}$ STF, HC 101244/MG, Rel. Min. Ricardo Lewandowski, Brasília, 16 de mar. 2010

42 Parte da doutrina não admitia o libelo bifronte, dividio em duas partes, uma dirigida ao juiz presidente e outra ao jurados.
} 
(Rangel, 2009, p.204). O Art.416 ${ }^{43}$ e seguintes que tratavam do libelo acusatório foram excluídos, dando lugar a uma fase de preparação do processo para o plenário, como preceituado pelo novo dispositivo:

Art.422. Ao receber os autos, o presidente do Tribunal do Júri determinará a intimação do órgão do Ministério Público ou do querelante, no caso de queixa, e do defensor, para, no prazo de 5 (cinco) dias, apresentarem rol de testemunhas que irão depor em plenário, até o máximo de 5 (cinco), oportunidade em que poderão juntar documentos e requerer diligência.

A segunda alteração, de não menos importância, é a forma e a ordem da quesitação. Os quisitos, são perguntas formuladas pelo juiz presidente, a serem respondidas pelos jurados com as palavras sim ou não. Os dois primeiros quisitos antes da reforma, não eram desmembrados, e portanto a autoria e a materialidade do delito pertenciam a somente uma quesitação. Com a reforma, isso foi alterado criando dois quesitos diversos, sendo o primeiro da materialidade e segundo da autoria. A nova forma tornou as perguntas formuladas mais céleres e objetivas, apresentando sua maior inovação na terceira quesitação, que trata da absolvição do acusado. Anteriormente, constava como quesitação causas de excludente de ilicitude, que exigia conhecimento necessário de ordem técnico-científica sobre o mérito da causa. $\mathrm{O}$ antigo Art.484, definia que:

III - qualquer fato ou circunstância que por lei isente de pena ou exclua o crime, ou o desclassifique, o juiz formulará os quesitos correspondentes, imediatamente depois dos relativos ao fato principal, inclusive os relativos ao excesso doloso ou culposo quando reconhecida qualquer excludente de ilicitude.

Com a mudança passou a constar da seguinte forma: "III - se o acusado deve ser absolvido".

Essa alteração foi alvo de críticas, pois pode implicar um grau maior de abstração e subjetividade por parte dos jurados, em vez de trazer mais

\footnotetext{
${ }^{43}$ A antiga redação era a seguinte: "Art.416. Passada em julgado a sentença de pronúncia, que especificará todas as circunstâncias qualificativas do crime e somente poderá ser alterada pela verificação superveniente de circunstância que modifique a classificação do delito, o escrivão imediatamente dará vista dos autos ao órgão do Ministério Público, pelo prazo de cinco dias, para oferecer o libelo acusatório"
} 
objetividade, uma vez que não abarca no quesito todas as causas de excludente ilicitude e culpabilidade. Mesmo porque, apesar de seguir o modelo do julgamento através da íntima convicção, podendo haver pronunciamento favorável aos dois primeiros quisitos, de materialidade e autoria, quais seriam os fundamentos da absolvição neste momento posterior.

O novo procedimento do Júri Popular passa a ser esquematizado da seguinte maneira:

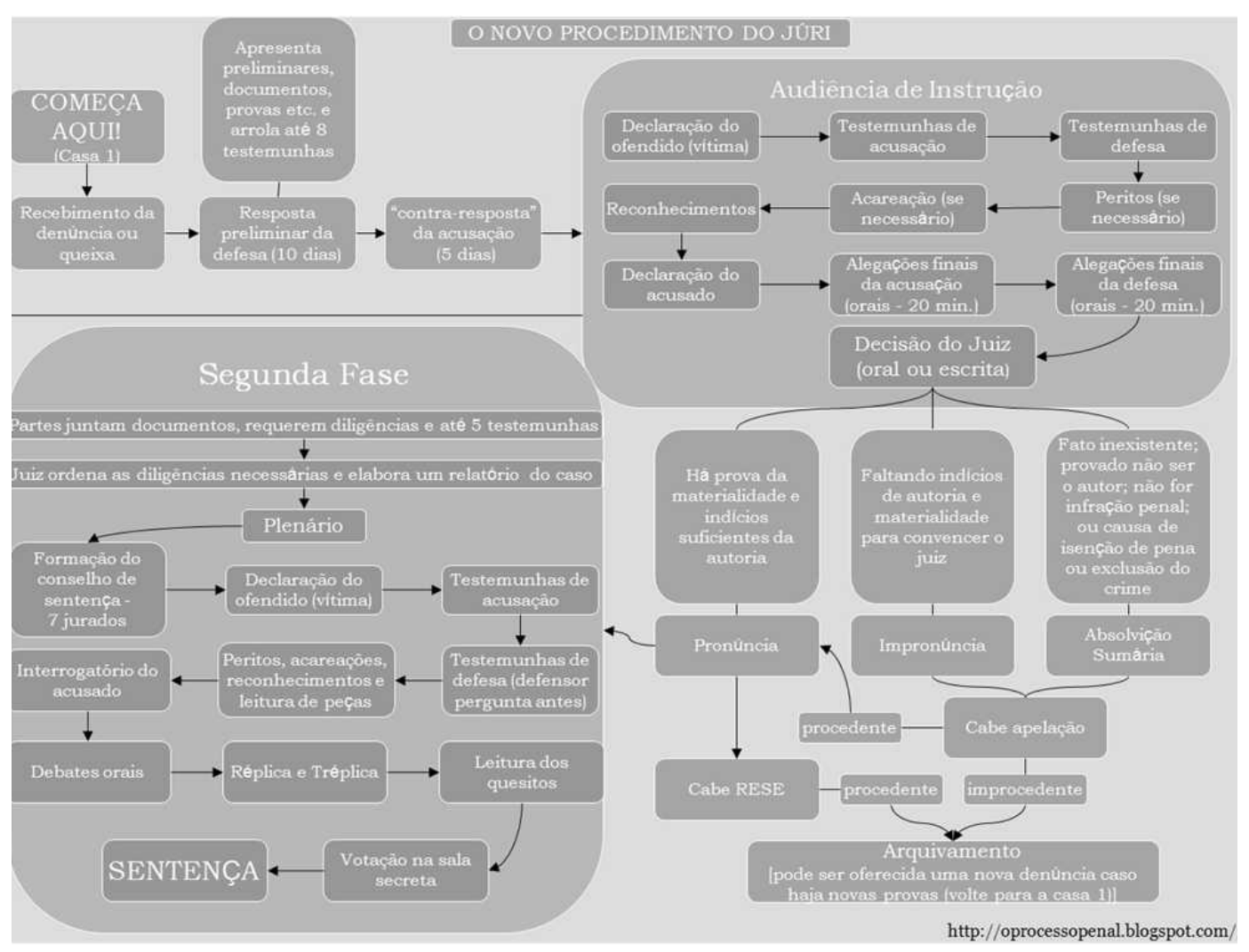

Figura 2. Novo procedimento do Júri ${ }^{44}$

\footnotetext{
${ }^{44}$ Retirado do blog: http://oprocessopenal.blogspot.com/
} 


\section{CONCLUSÃO}

Diante de tudo que até aqui foi exposto, com a tentativa de elucidar a construção histórica do Tribunal do Júri, suas características subjetivas e constitutivas, bem como o papel central das artes cênicas no contexto de julgamento, passamos, agora, a duas breves perguntas a fim de concluir. A primeira delas é o quão democrático pode ser este tipo de Tribunal, em uma sociedade marcada por grandes disparidades socio-econômicas. É possível separar tal contexto da subjetividade de cada um dos indíviduos que compõem o jurado e que devem julgar em acordo com sua convicção íntima?

Viver em uma sociedade, ainda mais como a brasileira, marcada por diversas mazelas históricas, é se deparar com graves injustiças, e com a exclusão e marginalização de vastos contingentes da população dos princípios fundamentais da cidadania.. A cultura brasileira se mostra, ademais, enraízada em preconceitos e pré-julgamentos, não porque assim somos em essência, mas por força de sua constituição histórica. A idéia de criminalidade nata, por exemplo, não faz sentido do ponto de vista biológico, e só pode, assim, estar disfarçando uma amostragem preconceituosa. $\mathrm{O}$ estímulo a políticas que melhorem a educação no país e reduzam as diferenças socio-econômicas, deveria ser o foco primordial para aqueles que governam em nome do povo. Por outro lado, a aceitação de que nunca existirá isonomia perfeita dentro de uma democracia, também faz parte de um processo intelectual ao qual a população deveria aderir, nunca deixando de respeitar os ordenamentos democráticos, que são primordias para o bom andar da carruagem.

A soberania exercida pelo povo, contudo, pode ser apenas aparente, pois a política no Brasil é geralmente feita por poucos cidadãos, que quase sempre buscam seus próprios interesses. Além disso, a própria Carta Constitucional ao instituir uma série de direitos antinômicos, promove 
dualidades que, normalmente, devem ser dirimidas pelo Judiciário, pois saber qual é o limite de seu direito, é uma tarefa árdua, já que sua vontade e liberdade são constritas.

No Júri, portanto, a democracia não enseja o julgamento de algo justo ou injusto, e sim o respeito às suas regras, leis, e procedimentos. Mesmo assim, Von Ilhering, em "A Evolução do Direito", exemplifica o perigo que pode haver nesse modelo de jugalmento do Júri Popular:

\begin{abstract}
"Cada recém-chegado recebe assim involuntária e inconscientemente a sua parte n'um thesouro de experiências e de modos de ver particulares, insensivelmente accumulados, que por sua vez conserva e transmitte. É a lei vital, não escripta, da classe em que elle se alista, desenvolvida sob a forma de espírito de casta. É sobre estes dois elementos - espírito continuo de uma virtude arvorada em dever, e influência moral da tradição - que se baseia a superioridade do juiz de carreira sobre o juiz da occasião - o jurado. Não se trata apenas de uma simples superioridade technica, a superioridade do profissional sobre o amador, de conhecimentos mais amplos, de uma habilidade superior, mas também de uma preeminência moral, qual é o hábito de obedecer á lei e o exercício da força de vontade para o fim determinado (...) emquanto o júry não tiver por missão julgar a lei em vez de julgar o accusado, todo veredictum d'este género é um acto miserável e arbitrário, uma revolta contra a ordem, uma insurreição contra a lei". (Ilhering, 1963, p.275-276)
\end{abstract}

A segunda pergunta que gostariar de deixar à título de conclusão refere-se à importância das artes dramáticas tanto no ritual do Júri, como em qualquer arguição em Tribunal, seja naqueles monocráticos, seja nos colegiados. A linguagem e seu uso performativo criam uma linha divisória no mundo jurídico entre aqueles que os dominam e aqueles que se abstém de tanto, restringindo sua atividade intelectual ao saber unicamente técnico da dogmática. Porém, tais capacidades não devem ser entedidos em separado, pois a teoria e a prática devem caminhar juntas de forma indissociável. No Tribunal do Júri, apesar de termos uma mudança substancial no acolhimento dos saberes técnicos, a influência destes ainda é grande, pois demonstra a posição que determinado indivíduo representa dentro daquele universos político, a qual o poder e o "status" sempre estarão em jogo. 
No Brasil, existe uma enorme dificuldade em conciliar-se o estudo de técnicas teatrais com o direito ${ }^{45}$. Nossas faculdades, em especial na graduação, não entendem que o domínio da linguagem oral e gestual faça parte de uma metodologia importante para os alunos de Direito. Outros, países, como os EUA, já avançaram sensivelmente em relação ao assunto. $\mathrm{Na}$ Universidade de Fordham, por exemplo, o professor de representação teatral, Michael Souveroff, já leciona uma oficina de teatro para futuros advogados, na companhia do professor de Direito da casa, James Cohen. A oficina tem o intuito de facilitar a comunicação e interação entre advogados e testemunhas, jurados ou mesmo juízes. Outros institutos também criaram oficinas com o mesmo viés, como a empresa Acting Law e o National Institute for Trial Advocacy, que promove uma série de cursos na Faculdade de Direito de Nova York. Segundo um artigo do Jornal ABA (American Bar Association):

"os advogados amam um palco. Afinal, existem muitas similaridades entre um palco do teatro e uma sala de julgamento (...) Mesmo que muitos advogados não façam questão de frequentar o teatro, eles gostam do que ele representa: a história, as questões, as palavras, o conflito, a retórica, a liturgia, o drama"46

$\mathrm{Na}$ mesma direção, o professor da Faculdade de Direito da Universidade de Nova Iorque, Richard K. Sherwin, foi pioneiro ao oferecer cursos em "persuasão visual no direito" (Visual Persuasion in the Law), desde 2001, com o objetivo de ensinar os estudantes sobre o papel, a eficácia e as armadilhas de usar-se evidências visuais em processos litigiosos. ${ }^{47}$ Em um artigo recente, publicado em francês, ele afirma:

"o direito sempre comportou uma parte performativa, em particular no tribunal. Com efeito, um processo responde às sete definições de performance formuladas por Richard Schchner em sua teoria fundadora. O processo performa um

\footnotetext{
45 Atualmente são raros os cursos de teatro para advogados nas Universidades brasieleiras. A $\mathrm{OAB}$ e algumas poucas instituições como a FAAp-SP, possuem oficinas com este intuito.

46 MELO, João Ozorio de. Curso de advogados ajuda a aprimorar atuação. Disponível em: $<$ http://www.conjur.com.br/2012-ago-02/curso-teatro-ajuda-advogados-aprimorar-atuacaotribunais>. Acesso em: 10/04/2016

47 Vale a pena conferir o site do projeto coordenado pelo Professor Sherwin: http://www.visualpersuasionproject.com/.
} 
momento de crise social e suas diferentes resoluções possíveis [...] O processo põe em cena uma narrativa elementar: algo perturbou o status quo e algo deve se passar para restaurar ou estabelecer uma nova ordem social. Para tanto, o processo recorre à diferentes formas de arte. A maneira pela qual os advogados constróem seus discursos é um exemplo disso, mas é também a utilização original que fazem das provas, assim como sua atividade corporal e verbal" (Sherwin 2013, p. 148 - tradução minha).

Existe também na França um interesse pela relação entre teatralidade e direito. Um exemplo disso é o dossiê com uma série de artigos publicado sobre o tema pela revista digital Criminocorpus. Um dos artigos nos interessa de perto. Ele provém da pena da Dra. Sandrine Zientara-Logeay, advogada da câmara criminal da Corte de cassação em Paris. A autora pergunta-se se a teatralidade na cena judiciária é um traço arcaico que deve ser extinto ou deve ser preservado. E continua,

"A dimensão teatral original do processo penal, visível tanto na cenografia judiciária quanto no procedimento e nas regras clássicas da tragédia, está hoje [...] posta em causa em duas frentes: aquela do imperativo de proximidade e aquela da exigência de gestão econômica.” (Zientara-Logeay 2013 - tradução minha).

Mas ela conclui que a dramaturgia judiciária é fundamental e indispensável por

"permitir que a justiça possa realizar plenamente sua missão de resolução do conflito, gerado pela violência privada, notadamente por meio do efeito de catarsis, que pode operar sobre o conjunto dos protagonistas da cena judicial, e por sua capacidade simbólica de reforçar a coesão social".

Não obstante, ela acrescenta ainda que se a teatralidade do processo penal deve ser preservada, isso deve se dar em um quadro modernizado que supõe "a introdução de um contraditório reforçado e de novas exigências éticas e deontológicas". Vemos, assim, que a teatralidade não é apenas um aspecto técnico do quadro judiciário, mas um elemento fundamental para a realização da justiça.

Entendemos, assim, que seria mais do que salutar se as Universidades pelo país revessem as metodologias de ensino unicamente técnicas, fomentadas por discussões doutrinárias e jurisprudenciais, que na 
maior parte das vezes esquecem justamente a necessidade da compreensão das relações humanas nas quais o Direito está imerso. 


\section{BIBLIOGRAFIA}

ANDRADE, Vera Regina Peireira. Sistema penal máximo $x$ cidadania mínima: Códigos de violência na era da globalização. Porto Alegre: Livraria do Advogado, 2003. 178p.

BACILA, Carlos Roberto. "Reescrevendo a história do direito penal a partir dos estigmas: O roteiro de uma tese". Direitos Fundamentais $e$ Democracia. Revista do Programa do Mestrado em Direito do UniBrasil. Curitiba, v.4, julho/dezembro 2008. Disponível em $<$ http://revistaeletronicardfd.unibrasil.com.br/index.php/rdfd/article/view/15 $5>.27 / 02 / 2016$.

BALANDIER, Georges. O poder em cena. Tradução por Luiz Tupy Caldas de Moura. Brasíia : UnB, 1982. 78p.

- Antropologia política. São Paulo, Difusão Européia do Livro, 1969. 192p.

BARATTA, Alessandro. Criminología crítica y crítica del derecho penal. 1.ed. Buenos Aires: Siglo XXI Editores Argentina, 2004. 264 p.

CARNICKE, Sharon Marie. "L'instinct théâtral: Evreinov et la théâtralité". Revue des Études Slaves. Paris, vol. 53, n. 1, p.97-108. 1981.

Disponível em $\quad<$ http://www.persee.fr/doc/slave_00802557_1981_num_53_1_5126>.26/03/2016

CHALITA, Gabriel. A sedução no discurso: O poder da linguagem nos tribunais de júri. 4. ed. São Paulo: Saraiva, 2007. 163p. 
CHAUÍ, Marilena. "Ideologia e Educação". Educação \& Sociedade. Revista Quadrimestral de Ciências da Educação. São Paulo: CEDES; Cortez Editora; Autores Associados, n.5, p.24-40, jan. 1980.

CUNHA, Euclides. Os sertões. São Paulo: Fundação Biblioteca Nacional e Ministério da Cultura, 1901.121p

FAUSTO, Boris. Crime e cotidiano. São Paulo: Brasiliense, 1984. 293p.

FERREIRA, Antonio Carlos. A escola positiva no Brasil: A influência da obra "O Homem Delinquente", de Cesare Lombroso, no Pensamento Penal e Criminológico Brasileiro entre 1900 e 1940. Criciúma. 2010. 83p. Monografia (Graduação em Direito) - Departamento de Direito da UNESC.

FOUCAULT, Michel. Vigiar e punir: Nascimento da prisão. Tradução por Raquel Ramalhete. 27.ed. Petrópolis: Vozes, 1987. 288 p

GERUDE, Fernando Gomes. As principais mudanças no Tribunal do Júri brasileiro trazidas pela Lei 11.689/08. Disponível em <http://www.ambitojuridico.com.br/site/index.php?artigo_id=7941\&n_link=revista_artigos_leit ura $>$. 28/04/2016.

HENRIQUES, Antonio. Argumentação e discurso jurídico. 2.ed. São Paulo: Atlas, 2008. 188p.

HUIZINGA, Johan. Homo ludens: O jogo como elemento da cultura. São Paulo: Perspectiva, 1980. 256p.

JHERING, Rudolf Von. A Evolução do direito. Lisboa: José Bastos \& Cia Editores, 1963. 376p. 
LEAL, Victor Nunes. Coronelismo, enxada e voto. 7.ed. São Paulo, 2012. $363 p$.

MARQUES, José Frederico. A instituição do júri. São Paulo: Saraiva, 1963. $302 p$.

MELO, João Ozorio de. Curso de advogados ajuda a aprimorar atuação. Disponível em <http:/www.conjur.com.br/2012-ago-02/curso-teatro-ajudaadvogados-aprimorar-atuacao-tribunais >. 10/04/2016.

OLIVEIRA, Heitor Moreira de; ATAÍDES, Maria Clara Capel de. Hermenêutica e Direito: Um olhar fenomenológico da performance. In: Anais do IV congresso de fenomenologia da região centro-oeste (eixo temático 5: Fenomenologia, arte e cultura) Goiânia: NEPEFE/FE-UFG, vol. 1, n. 1. 2011. Disponível em $<$ https://anaiscongressofenomenologia.fe.ufg.br/up/306/o/ComunHeitorMor eira.pdf>. 14/04/2016.

PERELMAN, Chaïm; OLBRECHTS-TYTECA, Lucie. Tratado de argumentação: A nova retórica. São Paulo: Martins Fontes, 1996. 680p.

PINTO, Luísa Fragoso Pereira. A história do Tribunal do Júri: Origem e evolução no sistema penal brasileiro. Disponível em $<$ http://www.tjrj.jus.br/c/document_library/get_file?uuid=c3c64982-cc8a4364-b36e-0b57aba2c7cc\&groupId=10136>. 11/02/2016

RANGEL, Paulo. Tribunal do Júri: Visão linguística, histórica, social e jurídica. 2.ed. Rio de Janeiro: Lumen Juris, 2009. 320p.

SAAD, Marta; MALAN, Diogo. Origens históricas dos sistemas acusatório e inquisitivo. n.842. São Paulo: Revista dos Tribunais, 2005. 28 p 
STANISLAVSKI, Konstantin. A construção da personagem. 4.ed. Tradução: Pontes de Paula Lima. Rio de Janeiro: Civilização Brasileira, 1986. 326p.

, Konstantin. A preparação do ator. Tradução: Pontes de Paula Lima. Rio de Janeiro: Civilização Brasileira, 1984. 365p.

SCHRITZMEYER, Ana Lúcia Pastore. Jogo, Ritual e Teatro: Um estudo antropológico do Tribunal do Júri. São Paulo: Terceiro Nome, 2012. 289 p.

- Controlando o poder de matar: uma leitura antropológica do Tribunal do Júri - ritual lúdico e teatralizado. São Paulo, 2002. 284p. Tese de Doutorado em Ciência Social (Antropologia Social). Universidade de São Paulo, USP, Brasil.

SHERWIN, Richard. "Présences et simulacres sur scène et au tribunal". Communications. Paris, n. 92, p. 147-158. 1/2013.

STRECK, Lênio Luiz. Tribunal do Júri: Símbolos e rituais. Porto Alegre: Livraria do Advogado, 2001. 183p.

VILELA, Lucila. A cortina como dromenon: Revelando Gustave Coubert e Robert Morris. Disponível em <http://interartive.org/2012/01/cortina/>. $15 / 03 / 2016$

ZAFFARONI, Eugênio Raul; PIERANGELI, José Henrique. Manual de direito penal brasileiro. 9.ed. São Paulo: Revista dos Tribunais, 2011. 766p. 
ZIENTARA-LOGEAY, Sandrine. "La théâtralité du procès pénal: entre archaisme et modernité". Criminocorpus [online] Disponível em < http://criminocorpus.revues.org/2376>. 19/05/2016. 